\title{
The Optimization of Nitrogen Fertilization Regulates Crop Performance and Quality of Processing Tomato (Solanum lycopersicum L. cv. Heinz 3402)
}

\author{
Spyridon A. Petropoulos $1, * \mathbb{C}$, Ângela Fernandes ${ }^{2, *} \mathbb{C}^{\mathbb{D}}$, Eustratios Xyrafis ${ }^{1}$, Nikolaos Polyzos ${ }^{1}{ }^{1}$, \\ Vasileios Antoniadis ${ }^{1}$, Lillian Barros ${ }^{2}$ (i) and Isabel C.F.R. Ferreira ${ }^{2}$ (i) \\ 1 Department of Agriculture Crop Production and Rural Environment, University of Thessaly, Fytokou Street, \\ 38446 Nea Ionia, Magnissia, Greece; stratosxy@hotmail.com (E.X.); niikpolyzos@gmail.com (N.P.); \\ antoniadis@uth.gr (V.A.) \\ 2 Campus de Santa Apolónia, Centro de Investigação de Montanha (CIMO), Instituto Politécnico de Bragança, \\ 5300-253 Bragança, Portugal; lillian@ipb.pt (L.B.); iferreira@ipb.pt (I.C.F.R.F.) \\ * Correspondence: spetropoulos@uth.gr (S.A.P.); afeitor@ipb.pt (Â.F.); Tel.: +30-2421-093-196 (S.A.P.)
}

Received: 29 April 2020; Accepted: 14 May 2020; Published: 16 May 2020

check for updates

\begin{abstract}
In this study, we evaluated the effect of various fertilization regimes on processing tomato (Solanum lycopersicum L. cv. Heinz 3402) yield and quality by applying the following treatments: (i) control (C), (ii) conventional fertilizer (21-0-0, N-P-K) (CF), (iii) slow release nitrogen fertilizer 46-0-0 (SR), (iv) conventional fertilizer (21-0-0, N-P-K) + Zeolite (CFZ), and v) composted sheep manure (M). The results of the study showed that the SR and CFZ treatments resulted in the highest fruit yield per hectare compared to the rest of the fertilizer and the control treatments. Fruit firmness was higher for the treatments $\mathrm{C}, \mathrm{M}$ and $\mathrm{SR}$, while color parameters (chroma and hue angle) were higher for the $\mathrm{C}$ and $\mathrm{M}$ treatments, respectively. Moreover, the total soluble solids content (TSS; ${ }^{\circ}$ Brix) was higher when manure (M) was applied. In terms of chemical composition, the total and individual tocopherols and sugars were the highest for the $\mathrm{M}$ and $\mathrm{C}$ treatments, respectively, whereas the oxalic, malic and total organic acid contents were the highest for the CFZ treatment. Moreover, the tested treatments showed a varied response in different antioxidant assays, although the $\mathrm{M}$ treatment exhibited a high antioxidant capacity in most of the assays, except for the $\beta$-carotene/linoleate assay. The carotenoid and chlorophyll contents were the highest for the control treatment. The main detected fatty acid was linoleic acid, followed by palmitic, oleic and $\alpha$-linolenic acid, while the CFZ treatment had the highest content of polyunsaturated fatty acids (PUFA) due to its high content of linoleic acid. In conclusion, although the application of fertilizers increased yield, the quality parameters and chemical composition showed a varied response to the fertilization regime, especially the TSS content and juice $\mathrm{pH}$ and electric conductivity (EC), which are significant for the marketability of the final product.
\end{abstract}

Keywords: antioxidant activity; carotene; lycopene; nitrogen fertilization; organic acids; processing tomato; Solanum lycopersicum cv. Heinz 3402; tocopherols; total soluble solids

\section{Introduction}

Tomato is considered as one of the most widely consumed vegetable crops, ranked second after potato [1]. It is cultivated throughout the world with an annual production of 182 million tons in 2018 harvested from approximately 4.8 million hectares [2]. Tomato fruit are used in various forms, including fresh fruit and processing products, while numerous genotypes exist in the market to satisfy market and consumer needs. Especially for processing tomato, plants must have specific characteristics aiming to improve their suitability for field crop cultivation and the processing industry and to meet the ever-changing market quality standards [3-7]. Tomato plays an important role in our eating habits 
due to its rich nutritional quality, which is reflected in the average annual consumption per capita of $20.5 \mathrm{~kg}$ [3], while according to The World Processing Tomato Council (WPTC), almost 40 million tons are consumed in the form of processed products, with a consumption per capita of $5.2 \mathrm{~kg}$ [8]. Fruit is a good source of lycopene, $\beta$-carotene, folate, potassium, ascorbic acid (vitamin $C$ ), tocopherols (vitamin E), flavonoids, phenolic compounds and xanthophylls [9-11], while many studies have pointed out the antioxidant potential and the bioactive properties of tomato fruit phytochemicals for reducing the risk of chronic diseases such as cancer [12-15].

Tomato is a very important crop for the European countries and the Mediterranean basin in particular, either as a field crop for processing tomato production or as a vegetable crop for table fruit production [1]. The crop's yield is highly dependent on nutrient availability in the soil; therefore, fertilization practices are of major importance to achieve high yields as well as products that meet market standards [16,17]. Processing tomato cropping systems are very intensive in terms of nutrient inputs, and usually, the applied fertilizer regimes aim to increase yield and easy to determine quality parameters such as the total soluble solids content (TSS; ${ }^{\circ}$ Brix), without considering nutrient use efficiency and optimal nutrient uptake from plants as well as other quality parameters [18]. Among the macronutrients, nitrogen has been recognized as one of the most important nutrients, since it affects not only the vegetative growth but also the fruit yield of a crop [19]. However, it is difficult to apply the optimum nitrogen rates in field crops such as processing tomato due to the soil variability, the nitrogen leaching and the soil denitrification, especially when considering that most of the farmers apply nutrients based on empirical practices and fertilizer companies recommendations and not according to the actual needs of plants during the growing period [20,21]. Various studies have pointed out that the maximum productivity occurs when soil texture remains constantly moist and nitrogen is available at the critical growth stage periods, whereas an inadequate nitrogen supply has severe effects on root growth that consequently affect plant growth and yield [22,23]. Moreover, the nitrogen form and farming systems such as crop rotation or organic cultivation may also affect nitrogen use efficiency and crop yield and quality [17,24-27]. Although mineral fertilization has been proved an effective tool to provide higher yields in crops, economic viability is always a major concern for the farmers due to the ever-increased production costs, so it is of paramount importance to come up with new strategies regarding the fertilizer regimes in terms of nutrient use efficiency and economic parameters [4,28].

Therefore, during the last decades, slow release nitrogen fertilizers have been introduced to the market as a new fertilizer management to achieve high yields in a cost-effective manner [29]. The benefits of slow release nitrogen fertilizers compared to the conventional ones are represented by the more even distribution of nutrients, the reduction of nitrogen losses due to leaching and run-off, and the improved availability of nitrogen at the various growth stages [30,31]. Although slow release nitrogen fertilizers present several benefits, they not gained wide acceptance among the farmers due to their higher cost, the unpredictability of nitrogen release as this depends on environmental conditions, and the fact that they do not provide rapid and visual plant growth [32,33]. The use of slow release fertilizers has also an environmental impact, since according to Fan and Li [29], who investigated the effects of two slow release nitrogen fertilizers on tomato growth and nitrogen leaching, the application of slow release fertilizers resulted in significantly less leaching than the ammonium nitrate treatment, which is essential for higher nutrient use efficiency and less pollution of groundwater reservoirs.

Moreover, the use of zeolite in agriculture has been investigated for its effects on the yield and the quality characteristics of crops, and it has been also proposed as a beneficial and eco-friendly fertilizer regime compared to conventional ones. Zeolite is a natural mineral part of hydrated aluminosilicates, whereas it has been shown that the addition of zeolites to the soil may promote plant growth, development and yield; improve water retention; enhance soil properties; and reduce nutrient losses [34]. Li et al. [35], who studied zeolite as a slow release fertilizer in spinach cultivation, reported that zeolite treatment increased crop yield over the conventional fertilizer. Moreover, farming practices that include combinatory applications of zeolite and composts may present various benefits, including an increase in water use efficiency and the improvement of soil properties and water holding 
capacity, while they may also help towards the reduction of soil degradation and the pollution of the environment [36-38].

Even though there have been several studies related to fertilizer management in processing tomato $[18,26,39,40]$, the application of novel technologies in fertilizer production and the introduction of high performance genotypes always create new challenges that have to be investigated. Moreover, most of the studies refer to the effect of nitrogen application rates on yield and simple fruit quality parameters such as $\mathrm{pH}, \mathrm{EC}$, TSS content and TA, and limited research exists about the effects on quality parameters estimated with advanced analytical techniques. Therefore, it is of paramount importance to evaluate new fertilization regimes that can promote the yield, the quality characteristics and the chemical and nutritional compositions of processing tomato fruit but also have an eco-friendly environmental aspect. Bearing these in mind, the aim of the present study was to evaluate the effect of different nitrogen fertilization regimes on the yield, the quality parameters and the chemical composition of processing tomato fruit cultivated in central Greece.

\section{Materials and Methods}

\subsection{Plant Material and Experimental Conditions}

The experiment was carried out in the experimental field of the University of Thessaly in Velestino, Greece. Tomato plants (Solanum lycopersicum L. cv. Heinz 3402) were obtained from a commercial nursery and transplanted to the field on May 7th 2015, five weeks after sowing. The total experimental area was $286 \mathrm{~m}^{2}$, arranged in 20 plots of $16 \mathrm{~m}^{2}(4 \times 4 \mathrm{~m})$ each with intervening and outlying corridors $1 \mathrm{~m}$ wide. Plants were placed with distances of $1 \mathrm{~m}$ between the rows and $0.33 \mathrm{~m}$ within each row. Each experimental plot included 5 rows of 10 plants each (50 plants in each plot and approximately 30,300 plants/ha). The present experiment is part of a series of trials carried out in the same field with the same treatment allocation and different crops (processing tomato, potato and onion), and here, we present the results regarding the processing tomato crop [41]. The soil conditions of the experimental field have been previously described by Karkanis and Petropoulos [42].

The fertilization regime was similar to that in a recent study published by our team where all the treatments and the used fertilizers are described in detail [41]. Briefly, five fertilizer treatments with four replications $(\mathrm{n}=4)$ were implemented as follows: (i) control (C), (ii) conventional fertilizer (21-0-0, N-P-K) (CF), (iii) slow release nitrogen fertilizer 46-0-0 (SR), (iv) conventional fertilizer (21-0-0, N-P-K) + Zeolite (CFZ), and v) composted sheep manure (M). With the exception of the control treatment where no synthetic fertilizers were added, all the treatments included a total amount of $250 \mathrm{~kg} / \mathrm{ha}$ of nitrogen $(\mathrm{N})$, phosphorus $(\mathrm{P})$ and potassium $(\mathrm{K})$, with differences in the form of the nitrogen added among them. In particular, $\mathrm{P}$ and $\mathrm{K}$ were applied with a base dressing on April 30th 2015, while nitrogen was applied with a single dose at base dressing in the SR treatment and with two side dressings in the CF and CFZ treatments. The sheep manure treatment did not include nitrogen in the form of synthetic fertilizers. Irrigation was applied via a sprinkler irrigation system at regular intervals and depending on the environmental conditions, while the control of weeds was achieved with manual hoeing throughout the growing period. For pest and pathogen control, a chemical management approach was followed based on the best practice guides and the recommended pesticides for the crop.

The harvest of mature fruit started at 77 days after transplantation (DAT; 22/07/2015) and was completed at 91 DAT (05/05/2015). The yield was estimated by the calculation of the total weight of the fruit harvested from the three middle rows of each row after excluding the two outer plants of the sides of each row ( 8 plants from each row and 24 plants from each plot). The dry matter content of the fruit was determined by putting freshly harvested fruit, cut into small pieces, in a forced-air oven drier at $72{ }^{\circ} \mathrm{C}$ until the weight of the samples was constant. For chemical analyses, ten fruit from each plot and treatment (40 fruit in total) were used to create three batch samples $(n=3)$, and then the fruit were cut into slices and stored under freezing conditions until lyophilization and further analysis. 
Three more batch samples $(n=3)$ were created in a similar manner for the determination of the quality parameters described below.

The determination of quality parameters such as $\mathrm{pH}$, titratable acidity (TA), total soluble solids $\left({ }^{\circ}\right.$ Brix) and color parameters (L, a, b, Chroma $(\mathrm{C})$, hue angle $(\mathrm{h})$ ) were determined according to the report described by Petropoulos et al. [43]. Firmness was evaluated with the use of a Turoni penetrometer (TR53205, TR Turoni srl, Forli, Italy) and a flat bottom probe ( $\mathrm{d}=9 \mathrm{~mm}$ and $9 \mathrm{~mm}$ width), while three measurements were recorded for each fruit at three different points of the equatorial axis in 15 fruits from each treatment ( 5 fruits from each batch sample) [43]. The electric conductivity (EC) and $\mathrm{pH}$ of juice were measured after reducing five fresh fruit from each batch sample to pulp with the use of a domestic electric blender, while three measurements were recorded for each treatment $(n=3)$ [44].

\subsection{Chemical Analyses}

\subsubsection{Nutritional and Energetic Value}

The powder from freeze-dried fruit was analyzed for proteins, fat, ash and carbohydrates according to the AOAC (Association of Official Analytical Chemists) procedures [45]. The crude protein content $(N \times 6.25)$ of the lyophilized samples was assessed by the macro-Kjeldahl (model Pro-Nitro-A, JP Selecta, Barcelona, Spain) method. Crude fat was estimated using a Soxhlet apparatus with petroleum ether. The ash content was determined by incineration (at $550 \pm 10^{\circ} \mathrm{C}$ ). Total carbohydrates were calculated by subtraction using the following equation: Total carbohydrates $(\mathrm{g} / \mathrm{kg}$ fresh weight $(\mathrm{fw}))=100-(\mathrm{g}$ $\mathrm{fat}+\mathrm{g}$ protein $+\mathrm{g}$ ash). Total energy was calculated according to the equation: Energy $(\mathrm{kcal} / \mathrm{kg} \mathrm{fw})=4$ $\times(\mathrm{g}$ protein $+\mathrm{g}$ carbohydrates $)+9 \times(\mathrm{g}$ fat $)$.

\subsubsection{Tocopherols}

The isoforms of tocopherols were also determined in the dried fruit powder, accordingly, by a procedure described by the authors [46]. Butylated hydroxytoluene (BHT) solution in n-hexane $(10 \mathrm{mg} / \mathrm{mL} ; 100 \mu \mathrm{L})$ and tocol solution in n-hexane (IS-Matreya, Pleasant Gap, PA, USA); $50 \mu \mathrm{g} / \mathrm{mL}$; $400 \mu \mathrm{L}$ ) were added to the sample prior to the extraction procedure. The samples $(500 \mathrm{mg})$ were homogenized with methanol $(4 \mathrm{~mL})$ by vortex mixing $(1 \mathrm{~min})$, then $\mathrm{n}$-hexane $(4 \mathrm{~mL})$ was added and the mixture was vortex mixed for $1 \mathrm{~min}$. After that, saturated $\mathrm{NaCl}$ aqueous solution $(2 \mathrm{~mL})$ was added, the mixture was homogenized ( $1 \mathrm{~min}$ ) and centrifuged $(5 \mathrm{~min}, 4000 \mathrm{~g})$, and the clear upper layer was carefully transferred to a vial. The sample was re-extracted twice with $n$-hexane. The combined extracts were taken to dryness under a nitrogen stream, redissolved in $2 \mathrm{~mL}$ of $\mathrm{n}$-hexane, dehydrated with anhydrous sodium sulfate, filtered through $0.2 \mu \mathrm{m}$ nylon filters from Whatman, transferred into a dark injection vial and analyzed by an HPLC system coupled to a fluorescence detector. The compounds were identified by chromatographic comparisons with authentic standards (Sigma-Aldrich, St. Louis, $\mathrm{MO}, \mathrm{USA}$ ), and the quantification was based on the fluorescence signal response, using the internal standard method. The results were expressed in mg per $\mathrm{kg}$ of fresh weight (fw).

\subsubsection{Soluble Sugars}

The soluble sugar content determination was also performed on the dried fruit powder following a procedure described by the authors. The samples $(1.0 \mathrm{~g})$ was spiked with melezitose as an internal standard (IS-Sigma, St. Louis, MO, USA; $5 \mathrm{mg} / \mathrm{mL}$ ) and extracted with $40 \mathrm{~mL}$ of $80 \%$ aqueous ethanol at $80{ }^{\circ} \mathrm{C}$ for $30 \mathrm{~min}$. The resulting suspension was centrifuged for $10 \mathrm{~min}$. The supernatant was concentrated at $40{ }^{\circ} \mathrm{C}$ (rotary evaporator) under reduced pressure and defatted three times with $10 \mathrm{~mL}$ of ethyl ether, successively. After concentration at $40^{\circ} \mathrm{C}$, the solid residues were dissolved in water to a final volume of $5 \mathrm{~mL}$ and filtered through $0.2 \mu \mathrm{m}$ nylon filters from Whatman for HPLC analysis. The compounds were identified by chromatographic comparisons with authentic standards (Sigma-Aldrich, St. Louis, MO, USA). The results were expressed in g per kg of fw. 


\subsubsection{Organic Acids}

Organic acid determination in the dried fruit powder was evaluated throughout an optimized procedure [47], using ultra-fast liquid chromatography equipment coupled to a photodiode array detector (UFLC-DAD); the samples (1.5 g) were subjected to an extraction with meta-phosphoric acid $\left(25 \mathrm{~mL} ; 25^{\circ} \mathrm{C} ; 150 \mathrm{rpm} ; 45 \mathrm{~min}\right)$, and filtered through Whatman No. 4 paper and $0.2 \mu \mathrm{m}$ nylon filters before injection; the organic acids were quantified by the comparison of the area of their peaks recorded at $215 \mathrm{~nm}$ with the calibration curves obtained from commercial standards (Sigma-Aldrich, St. Louis, $\mathrm{MO}, \mathrm{USA}$ ) of each compound. The results were expressed in $\mathrm{g}$ per $\mathrm{kg}$ of $\mathrm{fw}$.

\subsubsection{Pigments}

The contents of carotenoids and chlorophylls were evaluated using a method desribed by the authors [48]. Briefly, the samples $(500 \mathrm{mg}$ ) were vigorously shaken with $10 \mathrm{~mL}$ of acetone/hexane mixture $(4: 6, v / v)$ for $1 \mathrm{~min}$ and filtered through Whatman No. 4 filter paper. The absorbance was measured at 453,505, 645 and $663 \mathrm{~nm}$, and the contents of carotenoids ( $\beta$-carotene and lycopene) and chlorophyll $\mathrm{a}$ and $\mathrm{b}$ were obtained with the following equations, and expressed in $\mathrm{mg}$ per $\mathrm{kg}$ of $\mathrm{fw}$ : $\beta$-carotene $(\mathrm{mg} / 100 \mathrm{~mL})=0.216 \times \mathrm{A} 663-1.220 \times \mathrm{A} 645-0.304 \times \mathrm{A} 505+0.452 \times \mathrm{A} 453$; lycopene $(\mathrm{mg} / 100 \mathrm{~mL})=-0.0458 \times \mathrm{A} 663+0.204 \times \mathrm{A} 645-0.304 \times \mathrm{A} 505+0.452 \times \mathrm{A} 453 ;$ chlorophyll a $(\mathrm{mg} / 100 \mathrm{~mL})$ $=0.999 \times \mathrm{A} 663-0.0989 \times \mathrm{A} 645 ;$ chlorophyll $\mathrm{b}(\mathrm{mg} / 100 \mathrm{~mL})=-0.328 \times \mathrm{A} 663+1.77 \times \mathrm{A} 645$. The results were expressed in $\mathrm{mg}$ per $\mathrm{kg}$ of $\mathrm{fw}$.

\subsubsection{Fatty Acids}

The fatty acid profile was analyzed using gas-liquid chromatography with flame ionization detection (GC-FID) [46]. The fatty acids (obtained after Soxhlet extraction) were methylated with $5 \mathrm{~mL}$ of methanol/sulphuric acid/toluene 2:1:1 $(\mathrm{v} / \mathrm{v} / \mathrm{v})$ for at least $12 \mathrm{~h}$ in a bath at $50{ }^{\circ} \mathrm{C}$ and $160 \mathrm{rpm}$, then 3 $\mathrm{mL}$ of deionized water were added to obtain phase separation. The FAME (fatty acid methyl esters) were recovered with $3 \mathrm{~mL}$ of diethyl ether by shaking in vortex, and the upper phase was passed through a microcolumn of sodium sulfate anhydrous, in order to eliminate the water; the sample was recovered in a vial with Teflon, and before injection, the sample was filtered with $0.2 \mu$ m nylon filter paper from Whatman. Fatty acid identification was done by comparing the relative retention times of the FAME peaks from the samples with standards (reference standard mixture 37 (47885-U), Sigma-Aldrich, St. Louis, MO, USA). The results were recorded and processed using the Clarity 4.0.1.7 Software and expressed as the relative percentages of each fatty acid.

\subsubsection{Antioxidant Activity}

Powder from freeze-dried fruits was extracted by stirring with $30 \mathrm{~mL}$ of ethanol/water $(80: 20, v / v)$ for $1 \mathrm{~h}$ and subsequently filtering through Whatman No. 4 paper [49]. The residue was then extracted with an additional $30 \mathrm{~mL}$ of ethanol/water for $1 \mathrm{~h}$. The combined hydroethanolic extracts were evaporated to dryness and redissolved in ethanol/water for the evaluation of the antioxidant activity through the following assays.

DPPH radical-scavenging activity: This methodology was performed using an ELX800 Microplate Reader (Bio-Tek). The reaction mixture in each one of the 96-wells consisted of one of the different concentrations of the extracts $(30 \mu \mathrm{L})$ and a methanolic solution $(270 \mu \mathrm{L})$ containing DPPH radicals $(6 \times 10-5 \mathrm{~mol} / \mathrm{L})$. The mixture was left to stand for $60 \mathrm{~min}$ in the dark. The reduction of the DPPH radical was determined by measuring the absorption at $515 \mathrm{~nm}$. The radical scavenging activity (RSA) was calculated as a percentage of DPPH discoloration using the equation: $\% \mathrm{RSA}=\left[\left(A_{\mathrm{DPPH}}-\right.\right.$ $\left.\left.A_{\mathrm{S}}\right) / A_{\mathrm{DPPH}}\right] \times 100$, where $A_{\mathrm{S}}$ is the absorbance $(515 \mathrm{~nm}$ ) of the solution when the sample extract has been added at a particular level, and $A_{\mathrm{DPPH}}$ is the absorbance of the DPPH solution [49].

Ferricyanide/Prussian blue assay: The methodology was performed using the Microplate Reader described above. The different concentrations of the extracts $(0.5 \mathrm{~mL})$ were mixed with sodium 
phosphate buffer $(200 \mathrm{mmol} / \mathrm{L}, \mathrm{pH} 6.6,0.5 \mathrm{~mL})$ and potassium ferricyanide $(1 \% w / v, 0.5 \mathrm{~mL})$. For each concentration, the mixture was incubated at $50{ }^{\circ} \mathrm{C}$ for $20 \mathrm{~min}$, and trichloroacetic acid $(10 \% w / v, 0.5 \mathrm{~mL})$ was added. The mixture $(0.8 \mathrm{~mL})$ was poured into the 48 -well plates, as were deionized water $(0.8 \mathrm{~mL})$ and ferric chloride $(0.1 \% w / v, 0.16 \mathrm{~mL})$, and the absorbance was measured at $690 \mathrm{~nm}$ [49].

Inhibition of $\beta$-carotene bleaching: $\beta$-carotene $(2 \mathrm{mg})$ was dissolved in chloroform $(10 \mathrm{~mL})$, and $2 \mathrm{~mL}$ of this solution was pipetted into a round-bottom flask. After the chloroform was removed at $40^{\circ} \mathrm{C}$ under vacuum, linoleic acid (40 mg), Tween 80 emulsifier $(400 \mathrm{mg})$ and distilled water $(100 \mathrm{~mL})$ were added to the flask with vigorous shaking. Aliquots $(4.8 \mathrm{~mL})$ of this emulsion were transferred into different test tubes containing different concentrations of the extracts $(0.2 \mathrm{~mL})$. The tubes were shaken and incubated at $50{ }^{\circ} \mathrm{C}$ in a water bath. The zero time and endpoint $(2 \mathrm{~h})$ absorbance was measured at $470 \mathrm{~nm}$. The antioxidant activity was calculated using the following equation: (absorbance after $2 \mathrm{~h}$ of assay/initial absorbance) $\times 100$ [49].

Thiobarbituric acid reactive substances) (TBARS): Porcine (Sus scrofa) brains were obtained from official slaughtered animals, dissected, and homogenized with a Polytron in ice cold Tris- $\mathrm{HCl}$ buffer (20 mM, pH 7.4) to produce a 1:2 $w / v$ brain tissue homogenate, which was centrifuged at $3000 \mathrm{~g}$ for $10 \mathrm{~min}$. An aliquot $(100 \mu \mathrm{L})$ of the supernatant was incubated with the different concentrations of the sample solutions $(200 \mu \mathrm{L})$ in the presence of FeSO4 $(10 \mathrm{mM} ; 100 \mu \mathrm{L})$ and ascorbic acid $(0.1 \mathrm{mM}$; $100 \mu \mathrm{L})$ at $37^{\circ} \mathrm{C}$ for $1 \mathrm{~h}$. The reaction was stopped by the addition of trichloroacetic acid $(28 \% w / v$, $500 \mu \mathrm{L}$ ), followed by thiobarbituric acid (TBA, $2 \%, w / v, 380 \mu \mathrm{L}$ ), and the mixture was then heated at $80^{\circ} \mathrm{C}$ for $20 \mathrm{~min}$. After centrifugation at $3000 \mathrm{~g}$ for $10 \mathrm{~min}$ to remove the precipitated protein, the color intensity of the malondialdehyde (MDA)-TBA complex in the supernatant was measured by its absorbance at $532 \mathrm{~nm}$. The inhibition ratio (\%) was calculated using the formula: Inhibition ratio $(\%)=[(\mathrm{A}-\mathrm{B}) / \mathrm{A}] \times 100 \%$, where $\mathrm{A}$ and $\mathrm{B}$ were the absorbances of the control and the sample solutions, respectively [49]. The sample concentrations providing $50 \%$ of antioxidant activity or 0.5 of absorbance $\left(\mathrm{EC}_{50}\right)$ were determined from the graphs of antioxidant activity percentages (DPPH, $\beta$-carotene and TBARS assays) or absorbance at $690 \mathrm{~nm}$ (reducing power assay) against extract concentrations. Trolox was used as the standard (Sigma-Aldrich, St. Louis, MO, USA).

\subsection{Statistical Analysis}

The experiment was carried out according to the randomized complete block (RCB) design with four $(n=4)$ replications per treatment. For the quality parameter, nutritional value and chemical composition analyses, three batch samples $(n=3)$ were analyzed for each fertilization treatment and all the assays were performed in triplicate. For statistical analysis, the Statgraphics 5.1.plus (Statpoint Technologies, Inc., VA, USA) software was used. The obtained data were analyzed with one-way ANOVA for the main effect (fertilization regime), while the Duncan's multiple range test (DMRT) at $p=0.05$ was implemented for the comparison of means when a significant effect was detected.

\section{Results and Discussion}

The results regarding the total yield and fruit quality parameters are presented in Table 1. Significant differences were recorded for all the tested parameters in relation to the applied fertilizer regime. In particular, the highest total yield was achieved by the slow release nitrogen fertilizer (SR) and conventional fertilizer + zeolite (CFZ) treatments $(29,284 \pm 186 \mathrm{~kg} / \mathrm{ha}$ and $28,141 \pm 220 \mathrm{~kg} / \mathrm{ha}$, respectively), whereas the treatments where no synthetic nitrogen fertilizers were added (C and $M)$ presented the lowest yields. None of the applied fertilizer treatments had a significant effect on fruit juice $\mathrm{pH}$ compared to control (except for the $\mathrm{M}$ treatment where the lowest values were recorded), while no significant effects were observed on fruit juice titratable acidity (TA). Likewise, electric conductivity (EC) was the highest for those treatments where synthetic nitrogen fertilizers were added, whereas the total soluble solids (TSS) content was the highest for the manure treatment ( $5.44 \pm 0.43^{\circ}$ Brix). Finally, fruit firmness was the highest for the control treatment $(4.46 \pm 0.12 \mathrm{~kg})$. According to the literature, nitrogen fertilization rates may significantly affect the vegetative growth and total yield of processing 
tomato [50-53], while the effect of the nitrogen source has shown contradictory results, with some reports suggesting significant effects [26,54] while others report no effect at all [55]. However, although increasing nitrogen rates result in higher yields, the nitrogen use efficiency and agronomic efficiency were significantly reduced by increasing the rates, thus compromising farmers' incomes [56]. In the study of Ronga et al. [18], the rate of $200 \mathrm{~kg} / \mathrm{ha}$ of $\mathrm{N}$ was suggested as the best rate, since it resulted in the highest values for marketable and total yield, ${ }^{\circ}$ Brix values and marginal net return, whereas it showed the lowest global warming potential. In the same study, it was suggested that rates higher than $200 \mathrm{~kg}$ of $\mathrm{N} \mathrm{ha}^{-1}$ did not have a beneficial effect either on marketable and total yield or on fruit quality as determined through the TSS content [18]. Regarding the $\mathrm{pH}$ and titratable acidity, most of the studies refer to differences between organic and mineral fertilizers where a significant effect on fruit juice $\mathrm{pH}$ and no effects on TA were reported $[25,57,58]$. Moreover, similarly to in our study, Parisi et al. [59] did not observe any statistical differences in titratable acidity between different rates of nitrogen fertilization, although they reported significant differences in the TSS content ( ${ }^{\circ}$ Brix), which varied from 4.85 to 5.31. On the contrary, Zuba et al. [60], who investigated the yield and nutrition of tomato under different nutrient sources did not observe significant differences in the TSS content ( ${ }^{\circ}$ Brix), whereas Abu-Alrub et al. [61] observed a significant variation in fruit juice EC values as also reported in our study. Regarding fruit firmness, according to the results of Kalbani et al. [62], who estimated the effects of some organic fertilizers on the growth, yield and quality of tomato, a significant effect of nutrient source on fruit firmness was observed, while similar results were reported by Bilalis et al. [25]. In another study conducted by Chehade et al. [63], the use of different farming systems such as tillage and cover crops did not affect fruit quality parameters such as $\mathrm{pH}$, TSS content and firmness, indicating that apart from cultivation practices, these features are also genetically controlled [6]. Similarly, Colla et al. [64] suggested a variable effect of farming systems on processing tomato fruit quality over a two year experimental period, which further highlights the importance of the environmental conditions on quality parameters such as color score, TSS content and TA.

Table 1. Total yield, $\mathrm{pH}$, titratable acidity (TA), electrical conductivity (EC), total soluble solids ( ${ }^{\circ}$ Brix), and fruit firmness $(\mathrm{kg})$ of the processing tomato fruit in relation to the fertilization regime.

\begin{tabular}{ccccccc}
\hline Treatment & $\begin{array}{c}\text { Total Yield } \\
\mathbf{( k g} / \mathbf{h a})\end{array}$ & $\mathbf{p H}$ & TA & EC (mS/cm) & ${ }^{\circ}$ Brix & $\begin{array}{c}\text { Firmness } \\
\mathbf{( k g )}\end{array}$ \\
\hline $\mathrm{C}$ & $7312 \pm 93 \mathrm{c}$ & $4.14 \pm 0.07 \mathrm{a}$ & $0.51 \pm 0.01 \mathrm{a}$ & $4.33 \pm 0.02 \mathrm{~b}$ & $5.12 \pm 0.40 \mathrm{c}$ & $4.46 \pm 0.12 \mathrm{a}$ \\
$\mathrm{CF}$ & $25130 \pm 231 \mathrm{~b}$ & $4.16 \pm 0.04 \mathrm{a}$ & $0.57 \pm 0.03 \mathrm{a}$ & $4.70 \pm 0.01 \mathrm{a}$ & $5.25 \pm 0.36 \mathrm{~b}$ & $3.71 \pm 0.23 \mathrm{c}$ \\
$\mathrm{SR}$ & $29284 \pm 186 \mathrm{a}$ & $4.13 \pm 0.03 \mathrm{a}$ & $0.61 \pm 0.01 \mathrm{a}$ & $4.68 \pm 0.08 \mathrm{a}$ & $5.32 \pm 0.36 \mathrm{~b}$ & $4.23 \pm 0.19 \mathrm{~b}$ \\
$\mathrm{CFZ}$ & $28141 \pm 220 \mathrm{a}$ & $4.17 \pm 0.04 \mathrm{a}$ & $0.60 \pm 0.01 \mathrm{a}$ & $4.63 \pm 0.01 \mathrm{a}$ & $4.92 \pm 0.67 \mathrm{~d}$ & $3.79 \pm 0.31 \mathrm{c}$ \\
M & $7794 \pm 113 \mathrm{c}$ & $4.06 \pm 0.06 \mathrm{~b}$ & $0.53 \pm 0.01 \mathrm{a}$ & $4.37 \pm 0.32 \mathrm{~b}$ & $5.44 \pm 0.43 \mathrm{a}$ & $4.29 \pm 0.15 \mathrm{~b}$ \\
\hline
\end{tabular}

C: control, CF: conventional fertilizer, SR: slow release nitrogen fertilizer, CFZ: conventional fertilizer + zeolite, M: sheep manure. Mean values in the same column followed by different letters are significantly different at $p<0.05$ according to Duncan's multiple range test (DMRT).

Statistically significant differences were recorded for the color parameters of the fruit as affected by the applied fertilization regimes (Table 2). A variable response was observed for the tested parameters with the $\mathrm{M}$ and/or $\mathrm{C}$ treatments, showing the highest values in most of the cases. Despite the significant differences in the recorded mean values, no visual differences where detectable, which is due to the fact that all the fruit were hand-harvested at maturity stage and color differences were minimized. However, the observed trends could be significant when mechanical harvesting is applied and all fruit are harvested at the same time, regardless of maturity stage. Similar results have been also reported by Bilalis et al. [25], who evaluated the effects of organic and inorganic fertilization on the yield and quality of processing tomato in a two-year experiment and suggested that although color parameters differed among the fertilizer treatments, the color index (CI) - which represents the visual appearance of fruit-showed no significant differences. Moreover, Polat et al. [65] observed a significant effect of the nutrient source on color parameters, but a variable response from year to year was also reported, 
indicating the important role of environmental conditions on fruit quality and the maturation of processing tomato.

Table 2. Color evaluation of the processing tomato fruit in relation to the fertilization regime, expressed as co-ordinates $\mathrm{L}, \mathrm{a}, \mathrm{b}$, Chroma (C) and hue angle (h).

\begin{tabular}{cccccc}
\hline Treatment & $\mathbf{L}$ & $\mathbf{a}$ & $\mathbf{b}$ & Chroma & $\mathbf{h}$ \\
\hline $\mathrm{C}$ & $46.47 \pm 1.31 \mathrm{a}$ & $31.16 \pm 1.10 \mathrm{~b}$ & $37.98 \pm 2.21 \mathrm{a}$ & $49.02 \pm 1.01 \mathrm{a}$ & $50.36 \pm 1.11 \mathrm{a}$ \\
$\mathrm{CF}$ & $44.19 \pm 2.12 \mathrm{bc}$ & $31.32 \pm 2.03 \mathrm{~b}$ & $33.67 \pm 0.65 \mathrm{~b}$ & $46.07 \pm 2.03 \mathrm{~b}$ & $46.96 \pm 0.32 \mathrm{bc}$ \\
SR & $44.08 \pm 1.47 \mathrm{c}$ & $31.99 \pm 1.99 \mathrm{ab}$ & $33.37 \pm 1.23 \mathrm{~b}$ & $46.13 \pm 1.95 \mathrm{~b}$ & $46.15 \pm 1.23 \mathrm{bc}$ \\
CFZ & $43.08 \pm 2.01 \mathrm{c}$ & $30.80 \pm 0.89 \mathrm{~b}$ & $31.61 \pm 1.44 \mathrm{~b}$ & $44.20 \pm 0.64 \mathrm{c}$ & $45.61 \pm 2.54 \mathrm{c}$ \\
M & $45.65 \pm 3.01 \mathrm{ab}$ & $32.77 \pm 1.25 \mathrm{a}$ & $36.89 \pm 2.11 \mathrm{a}$ & $49.45 \pm 1.12 \mathrm{a}$ & $48.27 \pm 2.14 \mathrm{ab}$ \\
\hline
\end{tabular}

C: control, CF: conventional fertilizer, SR: slow release nitrogen fertilizer, CFZ: conventional fertilizer + zeolite, M: sheep manure. Mean values in the same column followed by different letters are significantly different at $p<0.05$ according to Duncan's multiple range test (DMRT).

Table 3 presents the results of the nutritional and energetic value of the processing tomato fruit in relation to the applied fertilization regimes. Regarding the moisture content, the CFZ treatment had the highest value $(950 \pm 4 \mathrm{~g} / \mathrm{kg} \mathrm{fw})$, and the control treatment, the lowest one (933 $\pm 6 \mathrm{~g} / \mathrm{kg} \mathrm{fw})$. Similarly to in our study, Ewulo et al. [66], who studied the effect of poultry manure application on selected chemical properties of tomato fruit, reported that various manure treatments may result in significant differences in terms of fruit moisture content. The fat content ranged from $1.18 \pm 0.02 \mathrm{~g} / \mathrm{kg}$ $\mathrm{fw}$ (CF treatment) to $0.80 \pm 0.01 \mathrm{~g} / \mathrm{kg}$ fw (SR), while protein content was also the highest for the CF treatment $(8.34 \pm 0.06 \mathrm{~g} / \mathrm{kg} \mathrm{fw})$. The ash content did not differ among the control $(\mathrm{C})$, manure $(\mathrm{M})$ and $\mathrm{CF}$ treatments, with values ranging between $5.1 \pm 0.2$ and $4.9 \pm 0.1 \mathrm{~g} / \mathrm{kg}$ fw. The control treatment had the highest carbohydrate content $(52.9 \pm 0.1 \mathrm{~g} / \mathrm{kg} \mathrm{fw})$, which also resulted in the highest energetic value $(251.0 \pm 0.4 \mathrm{kcal} / \mathrm{kg} \mathrm{fw})$. However, these findings could be the result of a concentration effect due to the lowest moisture content observed in this treatment, as already reported in the literature $[67,68]$. The highest content of carbohydrates in the control treatment could be also the result of the firmer and, probably, thicker skin, since according to Navarro-González et al. [69], a significant amount of carbohydrates are retained in peel fiber. The findings of this study regarding the observed variation in carbohydrate content has also been confirmed by Samaila et al. [70], who reported significant effects of mulching, irrigation intervals and nitrogen fertilizer rates on carbohydrate content in tomato fruit.

Table 3. Nutritional value $(\mathrm{g} / \mathrm{kg} \mathrm{fw})$ and energetic value $(\mathrm{kcal} / \mathrm{kg} \mathrm{fw})$ of processing tomato fruit in relation to the fertilization regime (mean $\pm \mathrm{SD}$ ).

\begin{tabular}{ccccccc}
\hline Treatment & Moisture & Fat & Proteins & Ash & Carbohydrates & Energy \\
\hline C & $933 \pm 6 \mathrm{e}$ & $0.84 \pm 0.06 \mathrm{c}$ & $8.0 \pm 0.1 \mathrm{~b}$ & $5.0 \pm 0.1 \mathrm{a}$ & $52.9 \pm 0.1 \mathrm{a}$ & $251.0 \pm 0.4 \mathrm{a}$ \\
$\mathrm{CF}$ & $938 \pm 8 \mathrm{~cd}$ & $1.18 \pm 0.02 \mathrm{a}$ & $8.34 \pm 0.06 \mathrm{a}$ & $5.1 \pm 0.2 \mathrm{a}$ & $47.6 \pm 0.2 \mathrm{c}$ & $234.5 \pm 0.5 \mathrm{c}$ \\
$\mathrm{SR}$ & $945 \pm 11 \mathrm{~b}$ & $0.80 \pm 0.01 \mathrm{~d}$ & $8.03 \pm 0.05 \mathrm{~b}$ & $4.5 \pm 0.4 \mathrm{~b}$ & $41.6 \pm 0.3 \mathrm{~d}$ & $205.7 \pm 0.9 \mathrm{~d}$ \\
CFZ & $950 \pm 4 \mathrm{a}$ & $0.93 \pm 0.01 \mathrm{~b}$ & $7.6 \pm 0.1 \mathrm{c}$ & $4.5 \pm 0.1 \mathrm{~b}$ & $36.75 \pm 0.03 \mathrm{e}$ & $185.8 \pm 0.2 \mathrm{e}$ \\
M & $935 \pm 2 \mathrm{de}$ & $0.91 \pm 0.06 \mathrm{~b}$ & $7.11 \pm 0.02 \mathrm{~d}$ & $4.9 \pm 0.1 \mathrm{a}$ & $52.45 \pm 0.01 \mathrm{~b}$ & $246.4 \pm 0.4 \mathrm{~b}$ \\
\hline
\end{tabular}

C: control, CF: conventional fertilizer, SR: slow release nitrogen fertilizer, CFZ: conventional fertilizer + zeolite, M: sheep manure. Mean values in the same column followed by different letters are significantly different at $p<0.05$ according to Duncan's multiple range test (DMRT).

The total and individual tocopherol contents are presented in Table 4. The main detected isoform of vitamin $\mathrm{E}$ was $\alpha$-tocopherol, followed by $\beta$-tocopherol. The manure treatment exhibited the highest $\alpha$ - and $\beta$-tocopherol content and, consequently, the highest total tocopherol content $(4.69 \pm 0.04 \mathrm{mg} / \mathrm{kg}$ $\mathrm{fw}, 0.155 \pm 0.003 \mathrm{mg} / \mathrm{kg} \mathrm{fw}$ and $4.85 \pm 0.04 \mathrm{mg} / \mathrm{kg}$ fw for $\alpha-, \beta$ - and total tocopherols, respectively). Similarly to in our study, $\alpha$-tocopherol was also the main detected tocopherol in the study of Abushita et al. [71], who tested 15 different processing tomato cultivars, but apart from $\alpha$-tocopherol, they also detected $\beta$ - and $\gamma$-tocopherol and $\alpha$-tocopherol quinone. This difference could be due to the sample 
preparation and harvesting stage, since seeds are the main source of $\gamma$-tocopherol and their presence in mature fruit could result in detectable amounts of $\gamma$-tocopherol in the obtained extracts $[72,73]$. Environmental conditions and genetic factors could be another explanation for these contradictory results, since according to Kacjan Maršić et al. [74], who detected $\alpha-, \gamma$ - and $\delta$-tocopherols in ten processing tomato varieties, the climate conditions and genotype may affect tocopherol composition. Helyes et al. [75] and Pék [76] suggested that the harvesting stage and water supply may affect the tocopherol composition, although varietal differences were also reported in this study. The tocopherol content in the raw material (fresh fruit) is very important since processing may result in significant losses of these antioxidant compounds and reduce the overall antioxidant potential of the processed products [71]. Moreover, a great amount of tocopherols remains in the processing byproducts, which makes more important the initial tocopherol content in the raw material as well as the valorization of the processing byproducts for antioxidant compound recovery [77].

Table 4. Composition, in terms of tocopherols $(\mathrm{mg} / \mathrm{kg} \mathrm{fw}$ ), of the processing tomato fruit in relation to the fertilization regime (mean $\pm \mathrm{SD})$.

\begin{tabular}{cccc}
\hline Treatment & $\alpha$-Tocopherol & $\beta$-Tocopherol & Total Tocopherols \\
\hline C & $4.22 \pm 0.02 \mathrm{~b}$ & $0.042 \pm 0.001 \mathrm{e}$ & $4.26 \pm 0.01 \mathrm{~b}$ \\
CF & $3.81 \pm 0.03 \mathrm{c}$ & $0.099 \pm 0.004 \mathrm{~b}$ & $3.91 \pm 0.03 \mathrm{c}$ \\
SR & $3.34 \pm 0.01 \mathrm{~d}$ & $0.084 \pm 0.005 \mathrm{c}$ & $3.42 \pm 0.01 \mathrm{~d}$ \\
CFZ & $2.96 \pm 0.02 \mathrm{e}$ & $0.078 \pm 0.003 \mathrm{~d}$ & $3.04 \pm 0.01 \mathrm{e}$ \\
M & $4.69 \pm 0.04 \mathrm{a}$ & $0.155 \pm 0.003 \mathrm{a}$ & $4.85 \pm 0.04 \mathrm{a}$ \\
\hline
\end{tabular}

C: control, CF: conventional fertilizer, SR: slow release nitrogen fertilizer, CFZ: conventional fertilizer + zeolite, M: sheep manure. Mean values in the same column followed by different letters are significantly different at $p<0.05$ according to Duncan's multiple range test (DMRT).

The effect of the fertilization regimes on the free sugar composition in processing tomato fruit is described in Table 5. The main detected sugars were fructose and glucose, which accounted for $98.6 \%-99.3 \%$ of the total sugar content, while sucrose was detected in low amounts $(0.170 \pm 0.001$ for the CFZ treatment to $0.36 \pm 0.02 \mathrm{~g} / \mathrm{kg}$ fw for the $C$ treatment). The same sugars were identified by García Herrera et al. [78] and Anthon et al. [79], while Zushi and Matsuzoe [69] also identified fructose and glucose as the major sugars in tomato fruit, followed by sucrose, which usually decreases at the red maturity stage [80]. According to our results, the control treatment gave the highest content of individual and total sugars, which could be partly ascribed to the concentration effect as already described in the results for nutritional value (see Table 3; $[67,68]$. This finding is also justified by the lowest content of individual and total sugars observed with the CFZ treatment, where the highest moisture content was recorded (see Table 3). By contrast, according to Valcárcel et al. [81], the observed increase in sugar content after the application of mild deficit irrigation is not ascertained by the higher accumulation of these compounds, since no significant effect of irrigation dose on sugar content was detected. Moreover, Parisi et al. [59] reported that increasing the rates of synthetic nitrogen fertilizers resulted in a significant decrease in fructose and sucrose content, which was also the case in our study. In the studies of Bénard et al. [82] and Wei et al. [83], it was reported that the glucose, sucrose and fructose contents were significantly affected by different levels of nitrogen, while Dabire et al. [84] suggested the effect of organic and mineral fertilizers on the chemical and biochemical compound contents in tomato. The effect of nitrogen supply on sugar content could be partially explained by the less dense canopy cover of crops under limited nitrogen rates, which results in increased light transmittance and exposure of tomato fruit to solar radiation, thus affecting the biosynthetic rates of sugars [82]. Farming systems may also affect glucose and fructose contents, since according to Lahoz et al. [80], organic farming resulted in increased contents of sugars and high ratios of sucrose equivalents to citric and glutamic acid, which are highly associated with fruit sweetness and consumer acceptability. 
Table 5. Composition, in terms of sugar $(\mathrm{g} / \mathrm{kg} \mathrm{fw})$, of the processing tomato fruit in relation to the fertilization regime (mean $\pm \mathrm{SD})$.

\begin{tabular}{ccccc}
\hline Treatment & Fructose & Glucose & Sucrose & Total Sugars \\
\hline C & $15.9 \pm 0.5 \mathrm{a}$ & $13.03 \pm 0.06 \mathrm{a}$ & $0.36 \pm 0.02 \mathrm{a}$ & $29.3 \pm 0.5 \mathrm{a}$ \\
$\mathrm{CF}$ & $13.1 \pm 0.2 \mathrm{c}$ & $9.0 \pm 0.1 \mathrm{c}$ & $0.24 \pm 0.02 \mathrm{c}$ & $22.3 \pm 0.1 \mathrm{c}$ \\
SR & $11.2 \pm 0.3 \mathrm{~d}$ & $7.5 \pm 0.5 \mathrm{~d}$ & $0.20 \pm 0.01 \mathrm{~d}$ & $18.9 \pm 0.8 \mathrm{~d}$ \\
CFZ & $9.7 \pm 0.2 \mathrm{e}$ & $6.0 \pm 0.1 \mathrm{e}$ & $0.170 \pm 0.001 \mathrm{e}$ & $15.8 \pm 0.3 \mathrm{e}$ \\
M & $14.6 \pm 0.3 \mathrm{~b}$ & $10.35 \pm 0.01 \mathrm{~b}$ & $0.33 \pm 0.03 \mathrm{~b}$ & $25.3 \pm 0.3 \mathrm{~b}$ \\
\hline
\end{tabular}

C: control, CF: conventional fertilizer, SR: slow release nitrogen fertilizer, CFZ: conventional fertilizer + zeolite, M: sheep manure. Mean values in the same column followed by different letters are significantly different at $p<0.05$ according to Duncan's multiple range test (DMRT).

The organic acid composition of the processing tomato fruit is presented in Table 6. Oxalic and malic acid were the most abundant organic acids followed by citric acid, whereas ascorbic acid was found in detectable amounts only in treatments where synthetic fertilizers were applied. By contrast, literature reports suggest citric acid as the main organic acid in tomato fruit $[48,68,79,83,85]$, being responsible for the titratable acidity of fruit juice. This difference could be attributed to the maturity stage and respirational loss of citric acid, as well as to the metabolic conversion of citric acid to sugars [79]. The highest individual and total organic acid contents were observed with the CFZ treatment $(0.57 \pm 0.01 \mathrm{~g} / \mathrm{kg} \mathrm{fw})$, while the lowest values were recorded with the SR treatment $(0.29 \pm 0.04 \mathrm{~g} / \mathrm{kg} \mathrm{fw})$. Similarly to in our study, Zhang et al. [86] reported that increased nitrogen availability resulted in an increase in organic acid content in spinach, while the nitrogen source may also affect organic acid content in edible greens $[87,88]$. Moreover, the addition of zeolite seems to have a beneficial effect on organic acid accumulation, a finding that is probably associated with the better nitrogen availability in soil after zeolite application [41,89]. Heeb et al. [90] also observed significant differences in citric and malic acid content when organic and inorganic fertilizers were applied in tomato plants, while these differences accreted when the nitrogen application rates were increased. According to $\mathrm{Du}$ et al. [50], the nitrogen application rate and the irrigation level may also affect organic acid content, with the highest content being observed when medium to high nitrogen levels ( 250 to $300 \mathrm{~kg} / \mathrm{ha}$ of $\mathrm{N}$ ) and medium irrigation levels ( $75 \%$ of cumulative evaporation; $\mathrm{E}_{\mathrm{p}}$ ) were applied, while similar results were reported by Wei et al. [83]. Finally, the environmental conditions and harvesting date may have an impact on organic acid content, especially when low amounts of nitrogen are supplied [82].

Table 6. Composition, in terms of organic acids ( $\mathrm{g} / \mathrm{kg} \mathrm{fw}$ ), of the processing tomato fruit in relation to the fertilization regime (mean $\pm \mathrm{SD}$ ).

\begin{tabular}{cccccc}
\hline Treatment & Oxalic Acid & Malic Acid & Ascorbic Acid & Citric Acid & Total Organic Acids \\
\hline C & $0.19 \pm 0.09 \mathrm{c}$ & $0.180 \pm 0.006 \mathrm{c}$ & $0.020 \pm 0.001 \mathrm{a}$ & $0.010 \pm 0.001 \mathrm{~b}$ & $0.4 \pm 0.1 \mathrm{c}$ \\
CF & $0.120 \pm 0.002 \mathrm{~d}$ & $0.180 \pm 0.002 \mathrm{c}$ & $\operatorname{tr}$ & $0.020 \pm 0.001 \mathrm{a}$ & $0.320 \pm 0.001 \mathrm{~d}$ \\
SR & $0.110 \pm 0.007 \mathrm{e}$ & $0.17 \pm 0.03 \mathrm{~d}$ & $\operatorname{tr}$ & $0.010 \pm 0.001 \mathrm{~b}$ & $0.29 \pm 0.04 \mathrm{e}$ \\
CFZ & $0.260 \pm 0.001 \mathrm{a}$ & $0.290 \pm 0.005 \mathrm{a}$ & $\operatorname{tr}$ & $0.020 \pm 0.001 \mathrm{a}$ & $0.57 \pm 0.01 \mathrm{a}$ \\
M & $0.200 \pm 0.001 \mathrm{~b}$ & $0.25 \pm 0.01 \mathrm{~b}$ & $0.010 \pm 0.001 \mathrm{~b}$ & $0.010 \pm 0.001 \mathrm{~b}$ & $0.47 \pm 0.01 \mathrm{~b}$ \\
\hline
\end{tabular}

Tr-traces. C: control, CF: conventional fertilizer, SR: slow release nitrogen fertilizer, CFZ: conventional fertilizer + zeolite, M: sheep manure. Mean values in the same column followed by different letters are significantly different at $p<0.05$ according to Duncan's multiple range test (DMRT).

Carotenoids and chlorophyll composition in the processing tomato fruit is presented in Table 7 . The highest amounts of the detected carotenoids ( $\beta$-carotene and lycopene) and chlorophylls (chlorophyll $a$ and $b$ ) were recorded for the control treatment. According to the literature, farming systems such as organic cultivation may affect lycopene content, although the results are not consistent when expressed on a dry weight basis, indicating a possible concentration effect [85]. This could be the case in our study, since increased lycopene content is usually associated with improved color [5], 
which was not observed with the corresponding control treatment (refer to the results in Table 2). Another aspect to be considered is the firmer and probably thicker skin of fruit with the control treatment, since according to Vinha et al. [91] and Toor and Savage [92], skins contain significant amounts of lycopene. Moreover, Verma et al. [93] suggested a significant variation of lycopene content in processing tomato fruit under different nutrient management practices, such as using composts, effective microorganisms and chemical fertilizers. Similarly, Zhang et al. [94] reported that nitrogen fertilizers mixed with manure resulted in the highest amounts of $\beta$-carotene, while they suggested a positive correlation of nitrogen rates with $\beta$-carotene content. Moreover, AL-khatani et al. [95] and Arthanari and Dhanapal [96] observed significant variations in chlorophyll content in tomato fruit cultivated under different fertilization regimes, whereas the latter [96] also suggested a negative correlation between chlorophyll content and carotenoids, which was not observed in our study. Considering that lycopene and $\beta$-carotene are the most abundant carotenoids in tomato fruit with significant antioxidant potential and health effects [97-99], agronomic practices that increase their content are very important and should be considered along with yield effects. The findings of our study indicate that although chemical fertilizers increase total yield, their effects on antioxidant compounds such as lycopene and $\beta$-carotene are not beneficial; therefore, integrated and sustainable practices such as manure and zeolite application along with chemical fertilizers should be considered.

Table 7. Carotenoid composition $(\mathrm{mg} / \mathrm{kg} \mathrm{fw})$ of the processing tomato fruit in relation to the fertilization regime (mean $\pm \mathrm{SD}$ ).

\begin{tabular}{ccccc}
\hline Treatment & $\beta$-Carotene & Lycopene & Chlorophyll a & Chlorophyll b \\
\hline C & $6.43 \pm 0.04 \mathrm{a}$ & $9.016 \pm 0.004 \mathrm{a}$ & $0.224 \pm 0.001 \mathrm{a}$ & $0.351 \pm 0.002 \mathrm{a}$ \\
CF & $4.483 \pm 0.005 \mathrm{c}$ & $6.050 \pm 0.003 \mathrm{c}$ & $0.136 \pm 0.001 \mathrm{c}$ & $0.187 \pm 0.002 \mathrm{~d}$ \\
SR & $3.965 \pm 0.005 \mathrm{~d}$ & $5.361 \pm 0.002 \mathrm{~d}$ & $0.132 \pm 0.001 \mathrm{c}$ & $0.183 \pm 0.001 \mathrm{~d}$ \\
CFZ & $4.08 \pm 0.01 \mathrm{~d}$ & $4.956 \pm 0.002 \mathrm{e}$ & $0.113 \pm 0.001 \mathrm{~d}$ & $0.224 \pm 0.002 \mathrm{c}$ \\
M & $5.341 \pm 0.002 \mathrm{~b}$ & $6.496 \pm 0.001 \mathrm{~b}$ & $0.154 \pm 0.001 \mathrm{~b}$ & $0.304 \pm 0.002 \mathrm{~b}$ \\
\hline
\end{tabular}

C: control, CF: conventional fertilizer, SR: slow release nitrogen fertilizer, CFZ: conventional fertilizer + zeolite, M: sheep manure. Mean values in the same column followed by different letters are significantly different at $p<0.05$ according to Duncan's multiple range test (DMRT).

The fatty acid compositions are presented in Table 8. Twenty-four individual fatty acids were detected in all the studied fruit samples, while the major one was linoleic acid, followed by palmitic and oleic acid. The fruit from treatments where synthetic nitrogen fertilizers were applied contained higher amounts of linolenic acid $(51.85 \% \pm 0.07 \%, 52.78 \% \pm 0.02 \%$ and $53.44 \% \pm 0.03 \%$, for the SR, CF and CFZ treatments, respectively) compared to the manure $(48.10 \% \pm 0.09 \%)$ and control treatments $(47.80 \% \pm 0.03 \%)$. For palmitic and oleic acid, the highest contents were recorded in the manure and control treatments, respectively. Most of the literature reports regarding the fatty acid content of processing tomato fruit refer to processing by-products [72,77]; however, similar fatty acid profiles were observed, with polyunsaturated fatty acids (PUFA) being the most abundant class, followed by saturated and unsaturated fatty acids (SFA and MUFA, respectively) [77]. The same fatty acids (linoleic, palmitic and oleic) were recently identified as the major ones in table tomato fruit by our team [48], although significant alterations in the fatty acid profile were observed at different harvesting dates. Similarly, according to Saini et al. [72], the fatty acid profile showed a significant variation during the maturation process, and linoleic acid increased at the red maturity stage whereas oleic acid decreased. Moreover, the PUFA/SFA ratio was higher than 0.45 with all the studied treatments, indicating good nutritional value, whereas the ratio of $\mathrm{n} 6 / \mathrm{n} 3$ fatty acids was higher than 4.0 regardless of the fertilizer regime, which, according to the literature, should be lower than 4.0 to indicate good nutritional quality $[100,101]$. 
Table 8. Fatty acid composition (relative \%) of the processing tomato fruit in relation to the fertilization regime (mean $\pm \mathrm{SD})$.

\begin{tabular}{|c|c|c|c|c|c|}
\hline & $\mathrm{C}$ & $\mathrm{CF}$ & SR & CFZ & $\mathbf{M}$ \\
\hline C6:0 & $0.071 \pm 0.001 \mathrm{a}$ & $0.063 \pm 0.001 b$ & $0.038 \pm 0.004 c$ & $0.028 \pm 0.001 \mathrm{~d}$ & $0.073 \pm 0.001 \mathrm{a}$ \\
\hline C8:0 & $0.036 \pm 0.001 c$ & $0.047 \pm 0.002 b$ & $0.023 \pm 0.001 \mathrm{~d}$ & $0.021 \pm 0.001 \mathrm{~d}$ & $0.060 \pm 0.004 \mathrm{a}$ \\
\hline C10:0 & $0.042 \pm 0.001 \mathrm{a}$ & $0.043 \pm 0.003 a$ & $0.019 \pm 0.001 b$ & $0.016 \pm 0.001 c$ & $0.042 \pm 0.004 \mathrm{a}$ \\
\hline C12:0 & $0.080 \pm 0.004 \mathrm{a}$ & $0.060 \pm 0.003 c$ & $0.058 \pm 0.004 c$ & $0.053 \pm 0.002 \mathrm{~d}$ & $0.074 \pm 0.001 \mathrm{~b}$ \\
\hline C13:0 & $0.072 \pm 0.004 \mathrm{a}$ & $0.037 \pm 0.003 \mathrm{~d}$ & $0.049 \pm 0.004 b$ & $0.042 \pm 0.001 \mathrm{c}$ & $0.071 \pm 0.005 a$ \\
\hline C14:0 & $0.455 \pm 0.004 b$ & $0.354 \pm 0.004 c$ & $0.329 \pm 0.008 \mathrm{~d}$ & $0.263 \pm 0.002 \mathrm{e}$ & $0.51 \pm 0.01 \mathrm{a}$ \\
\hline C15:0 & $0.122 \pm 0.002 b$ & $0.103 \pm 0.001 \mathrm{c}$ & $0.106 \pm 0.004 \mathrm{c}$ & $0.093 \pm 0.004 \mathrm{~d}$ & $0.130 \pm 0.002 \mathrm{a}$ \\
\hline C16:0 & $19.12 \pm 0.02 b$ & $17.10 \pm 0.04 \mathrm{~d}$ & $17.40 \pm 0.04 c$ & $17.32 \pm 0.05 c$ & $19.4 \pm 0.1 \mathrm{a}$ \\
\hline C16:1 & $0.304 \pm 0.002 b$ & $0.249 \pm 0.001 \mathrm{~d}$ & $0.284 \pm 0.004 \mathrm{c}$ & $0.248 \pm 0.001 \mathrm{~d}$ & $0.321 \pm 0.008 \mathrm{a}$ \\
\hline C17:0 & $0.268 \pm 0.004 b$ & $0.251 \pm 0.001 \mathrm{c}$ & $0.270 \pm 0.004 b$ & $0.251 \pm 0.005 c$ & $0.338 \pm 0.008 a$ \\
\hline C18:0 & $5.45 \pm 0.01 b$ & $5.84 \pm 0.01 \mathrm{a}$ & $5.40 \pm 0.01 b c$ & $5.37 \pm 0.01 c$ & $5.80 \pm 0.01 \mathrm{a}$ \\
\hline $\mathrm{C} 18: 1 n 9 \mathrm{c}$ & $15.68 \pm 0.02 \mathrm{a}$ & $15.22 \pm 0.02 b$ & $13.40 \pm 0.02 \mathrm{e}$ & $13.82 \pm 0.01 \mathrm{~d}$ & $14.67 \pm 0.03 c$ \\
\hline $\mathrm{C} 18 \mathrm{2} 2 \mathrm{n} 6 \mathrm{c}$ & $47.80 \pm 0.03 \mathrm{e}$ & $52.78 \pm 0.02 b$ & $51.85 \pm 0.07 c$ & $53.44 \pm 0.03 a$ & $48.10 \pm 0.09 \mathrm{~d}$ \\
\hline C18:3n3 & $7.13 \pm 0.03 b$ & $5.52 \pm 0.02 \mathrm{~d}$ & $8.02 \pm 0.01 \mathrm{a}$ & $6.82 \pm 0.01 c$ & $6.91 \pm 0.01 \mathrm{c}$ \\
\hline C20:0 & $0.55 \pm 0.02 \mathrm{~d}$ & $0.59 \pm 0.02 \mathrm{c}$ & $0.684 \pm 0.003 \mathrm{a}$ & $0.619 \pm 0.006 b$ & $0.59 \pm 0.03 c$ \\
\hline C20:1 & $0.067 \pm 0.001 \mathrm{~d}$ & $0.077 \pm 0.002 \mathrm{c}$ & $0.100 \pm 0.001 \mathrm{a}$ & $0.077 \pm 0.004 \mathrm{c}$ & $0.083 \pm 0.002 b$ \\
\hline C20:2 & $0.135 \pm 0.001 \mathrm{a}$ & $0.043 \pm 0.004 \mathrm{~d}$ & $0.104 \pm 0.004 b$ & $0.059 \pm 0.001 \mathrm{c}$ & $0.105 \pm 0.004 b$ \\
\hline $\mathrm{C} 20: 3 \mathrm{n} 3+\mathrm{C} 21: 0$ & $0.077 \pm 0.001 \mathrm{e}$ & $0.088 \pm 0.001 \mathrm{~d}$ & $0.11 \pm 0.01 \mathrm{~b}$ & $0.104 \pm 0.004 \mathrm{c}$ & $0.202 \pm 0.004 \mathrm{a}$ \\
\hline C20:5n3 & $1.03 \pm 0.01 b$ & $0.45 \pm 0.02 \mathrm{~d}$ & $0.50 \pm 0.02 c$ & $0.28 \pm 0.02 \mathrm{e}$ & $0.211 \pm 0.005 a$ \\
\hline $\mathrm{C} 22: 0$ & $0.410 \pm 0.007 c$ & $0.39 \pm 0.02 \mathrm{~d}$ & $0.437 \pm 0.003 b$ & $0.39 \pm 0.01 \mathrm{~d}$ & $1.28 \pm 0.01 \mathrm{a}$ \\
\hline $\mathrm{C} 22: \ln 9$ & $0.52 \pm 0.02 \mathrm{a}$ & $0.23 \pm 0.01 \mathrm{~d}$ & $0.273 \pm 0.004 \mathrm{c}$ & $0.183 \pm 0.001 \mathrm{e}$ & $0.307 \pm 0.003 b$ \\
\hline C22:2 & $0.070 \pm 0.006 \mathrm{a}$ & $0.038 \pm 0.001 \mathrm{c}$ & $0.048 \pm 0.001 b$ & $0.046 \pm 0.004 b$ & $0.067 \pm 0.002 \mathrm{a}$ \\
\hline C23:0 & $0.218 \pm 0.001 c$ & $0.20 \pm 0.01 c$ & $0.23 \pm 0.001 b$ & $0.227 \pm 0.001 b$ & $0.315 \pm 0.009 a$ \\
\hline C24:0 & $0.298 \pm 0.001 b$ & $0.232 \pm 0.003 \mathrm{e}$ & $0.277 \pm 0.001 \mathrm{c}$ & $0.241 \pm 0.002 \mathrm{~d}$ & $0.374 \pm 0.009 a$ \\
\hline Total SFA ( $\%$ of total FA) & $27.19 \pm 0.01 \mathrm{~b}$ & $25.30 \pm 0.01 \mathrm{c}$ & $25.32 \pm 0.03 c$ & $24.9 \pm 0.1 \mathrm{~d}$ & $29.0 \pm 0.1 \mathrm{a}$ \\
\hline Total MUFA ( $\%$ of total FA) & $16.56 \pm 0.05 \mathrm{a}$ & $15.78 \pm 0.03 b$ & $14.06 \pm 0.02 \mathrm{e}$ & $14.32 \pm 0.01 \mathrm{~d}$ & $15.38 \pm 0.02 c$ \\
\hline Total PUFA ( $\%$ of total FA) & $56.25 \pm 0.05 \mathrm{~d}$ & $58.92 \pm 0.02 c$ & $60.63 \pm 0.05 b$ & $60.75 \pm 0.06 \mathrm{a}$ & $55.6 \pm 0.1 \mathrm{e}$ \\
\hline PUFA/SFA & $2.07 \pm 0.03 \mathrm{~d}$ & $2.33 \pm 0.01 \mathrm{c}$ & $2.39 \pm 0.04 b$ & $2.44 \pm 0.03 \mathrm{a}$ & $1.92 \pm 0.15 \mathrm{e}$ \\
\hline n6/n3 & $5.83 \pm 0.03 \mathrm{e}$ & $8.72 \pm 0.02 \mathrm{a}$ & $6.02 \pm 0.01 \mathrm{~d}$ & $7.43 \pm 0.02 \mathrm{~b}$ & $6.59 \pm 0.04 \mathrm{c}$ \\
\hline
\end{tabular}

Caprylic acid (C8:0); capric acid (C10:0); lauric acid (C12:0); tridecylic acid (C13:0); myristic acid (C14:0); pentadecylic acid (C15:0); palmitic acid (C16:0); palmitoleic acid (C16:1); margaric acid (C17:0); stearic acid (C18:0); oleic acid (C18:1n9); linoleic acid (C18:2n6c); $\alpha$-linolenic acid (C18:3n3); arachidic acid (C20:0); 11-eicosenoic acid (C20:1); eicosadienoic acid (C20:2); eicosatrienoic acid (C20:3n3); heneicosylic acid (C21:0); eicosapentaenoic acid (C20: $5 \mathrm{n} 3)$; behenic acid (C22:0); erucic acid (C22:1n9); docosadienoic acid (C22:2); tricosylic acid (C23:0); lignoceric acid (C24:0); SFA: saturated fatty acids; MUFA: monounsaturated fatty acids; PUFA: polyunsaturated fatty acids; n6/n3: omega-6/omega-3 fatty acids; C: control; CF: conventional fertilizer; SR: slow release nitrogen fertilizer; CFZ: conventional fertilizer + zeolite; M: sheep manure. Mean values in the same row followed by different letters are significantly different at $p<0.05$ according to Duncan's multiple range test (DMRT).

The antioxidant properties of the processing tomato fruit are presented in Table 9, and a varied response to the fertilization regime was observed depending on the performed assay. In particular, the control treatment showed the lowest $\mathrm{EC}_{50}$ values in all the assays, except for the case of DPPH scavenging activity where the manure treatment was more effective. The present findings could be associated with the high content of antioxidant compounds such as carotenoids and tocopherols with the control and manure treatments, respectively, since the role of these compounds in the antioxidant activity of tomato fruit is well confirmed [74,77,102,103]. Moreover, Raiola et al. [104], who evaluated lipophilic (LAA) and hydrophilic (HAA) antioxidant activity in processed tomato fruit, suggested that the carotenoid and $\beta$-carotene contents do not correlate with LAA and that other compounds such as tocopherols should be considered responsible for these activities. As already mentioned for the carbohydrate and lycopene contents (refer to Tables 3 and 7), the highest antioxidant activity for the control treatment could be attributed to the firmer and thicker skin, which is richer in antioxidant compounds than the rest of the fruit fractions (pulp and seeds) [91,92,105]. Similar activity to that with the control treatment was observed in the reducing power and the $\beta$-carotene/linoleate assays, where the manure and CF treatments were equally effective. This variable response could be attributed to differences in the sensitivity of the performed assays to specific phytochemicals, as well as to the extraction protocols performed [48,106-108]. Moreover, according to Ilić et al. [109], the effect of 
the farming system on the antioxidant properties of tomato fruit did not show consistency, and any differences could be attributed to differences in nutrient sources and the accumulation of secondary metabolites related to stressors. On the other hand, the results of this research are in agreement with the findings of Toor et al. [110], who reported significant differences in the antioxidant properties of tomato fruit fertilized with different types of fertilizer (organic and synthetic ones). Similarly, Sereme et al. [111] reported a significant effect of the type of fertilizer (organic and mineral) and the harvesting date on the antioxidant activity of tomato fruit, while they suggested a positive correlation of such activities with total phenolic compound content.

Table 9. Antioxidant properties $\left(\mathrm{EC}_{50} ; \mathrm{mg} / \mathrm{mL}\right)$ of the processing tomato fruit in relation to the fertilization regime (mean $\pm \mathrm{SD})$.

\begin{tabular}{|c|c|c|c|c|}
\hline \multirow[b]{2}{*}{ Treatment } & \multirow{2}{*}{$\begin{array}{c}\text { Reducing Power } \\
\text { Ferricyanide/Prussian } \\
\text { Blue } \\
\left(E_{50} ; \mathrm{mg} / \mathrm{mL}\right)\end{array}$} & \multicolumn{2}{|c|}{ Radical Scavenging Activity } & \multirow{2}{*}{$\begin{array}{c}\begin{array}{c}\text { Lipid Peroxidation } \\
\text { Inhibition }\end{array} \\
\text { TBARS } \\
\left(\mathrm{EC}_{50} ; \mathrm{mg} / \mathrm{mL}\right)\end{array}$} \\
\hline & & $\begin{array}{c}\text { DPPH Scavenging } \\
\text { Activity } \\
\left(\mathrm{EC}_{50} ; \mathrm{mg} / \mathrm{mL}\right)\end{array}$ & $\begin{array}{c}\beta \text {-Carotene } / \text { Linoleate } \\
\left(\mathrm{EC}_{50} ; \mathrm{mg} / \mathrm{mL}\right)\end{array}$ & \\
\hline $\mathrm{C}$ & $0.733 \pm 0.002 \mathrm{~d}$ & $6.5 \pm 0.1 \mathrm{~d}$ & $0.478 \pm 0.001 \mathrm{~d}$ & $0.32 \pm 0.03 \mathrm{~d}$ \\
\hline CF & $0.75 \pm 0.01 \mathrm{a}$ & $6.7 \pm 0.1 c$ & $0.470 \pm 0.005 \mathrm{e}$ & $0.43 \pm 0.02 b$ \\
\hline SR & $0.739 \pm 0.003 c$ & $7.9 \pm 0.2 \mathrm{a}$ & $0.49 \pm 0.01 \mathrm{c}$ & $0.40 \pm 0.02 c$ \\
\hline CFZ & $0.741 \pm 0.001 \mathrm{~b}$ & $7.6 \pm 0.1 \mathrm{~b}$ & $0.59 \pm 0.01 \mathrm{~b}$ & $0.50 \pm 0.01 \mathrm{a}$ \\
\hline M & $0.732 \pm 0.005 \mathrm{~d}$ & $6.1 \pm 0.1 \mathrm{e}$ & $0.598 \pm 0.003 \mathrm{a}$ & $0.49 \pm 0.02 \mathrm{a}$ \\
\hline
\end{tabular}

$\mathrm{EC}_{50}$ : extract concentration corresponding to $50 \%$ of antioxidant activity, C: control, CF: conventional fertilizer, SR: slow release nitrogen fertilizer, CFZ: conventional fertilizer + zeolite, M: sheep manure. Mean values in the same column followed by different letters are significantly different at $p<0.05$ according to Duncan's multiple range test (DMRT).

\section{Conclusions}

According to the results of this study, significant differences related to the yield, the quality parameters and the chemical composition of the processing tomato fruit were observed according to the applied fertilizer treatments. Slow release nitrogen fertilizer (SR) and conventional fertilizer + zeolite (CFZ) resulted in the highest yields compared to the rest of the fertilizer and the control treatments, whereas the color parameters were positively affected by the control and manure treatments but without differences in visual appearance detectable to the naked eye. The manure treatment had a beneficial effect on the fruit juice $\mathrm{pH}$ and total soluble solid content, whereas titratable acidity was not significantly affected by the fertilization regime. Moreover, the nutritional value was affected by the fertilization regime, although a concentration effect is implied due to the expression of the results on a fresh weight basis. Regarding the chemical composition, the control and manure treatments had beneficial effects on the sugar and tocopherol contents, respectively, while for organic acids, the combination of conventional fertilizers and zeolite gave the best results. Carotenoids and chlorophylls had the highest contents with the control treatment, while antioxidant activity showed a variable response to the applied fertilizer treatments, although the manure treatment showed the best results for most of the performed assays. The fatty acid profile was also affected by the applied fertilizer regime with palmitic and oleic acid having the highest contents with the manure and control treatments, respectively. In conclusion, although the slow release nitrogen fertilizer and conventional fertilizer + zeolite treatments were the best in terms of total yield, most of the quality related parameters were better with the control and manure treatments, except for the TSS content, which is essential for the marketing of the final product and was the lowest for the control treatment. Therefore, the great differences in terms of yield between the tested treatments do not allow for viable incomes when the control or manure treatments are applied, and further approaches for sustainable farming have to be studied (e.g., manure and/or zeolite application, varying the time of application, etc.) in order to achieve high yields without compromising the overall quality of the obtained product. 
Author Contributions: Conceptualization, S.A.P., V.A. and I.C.F.R.F.; methodology, A.F., E.X. and L.B.; investigation A.F., E.X. and N.P.; data curation, A.F., N.P. and L.B.; writing-original draft preparation N.P., S.A.P.; writing-review and editing S.A.P., V.A., L.B. and I.C.F.R.F.; visualization, S.A.P., V.A. and I.C.F.R.F.; supervision, S.A.P., V.A. and I.C.F.R.F.; project administration, S.A.P. and I.C.F.R.F.; funding acquisition, A.F and L.B. All authors have read and agreed to the published version of the manuscript.

Funding: Foundation for Science and Technology (FCT, Portugal) and FEDER, grant number (UIDB/00690/2020).

Acknowledgments: The authors would like to thank Souipas Spyridon for their technical assistance throughout the growing period of the experiment. The authors are also grateful to the Foundation for Science and Technology (FCT, Portugal) and FEDER under Programme PT2020 for financial support to CIMO (UIDB/00690/2020), national funding by FCT, P.I., through the institutional scientific employment program-contract for A. Fernandes and L. Barros contracts.

Conflicts of Interest: The authors declare no conflict of interest.

\section{References}

1. FAO FAOSTAT. Production and Trade Statistics. Available online: http://www.fao.org/faostat/en/\#data/QC/ visualize (accessed on 30 April 2020).

2. FAO. FAOSTAT Crops. In FAO Statistics Division; Food Agricultural Organization of the United Nations: Rome, Italy, 2017.

3. Bergougnoux, V. The history of tomato: From domestication to biopharming. Biotechnol. Adv. 2014, 32, 170-189. [CrossRef] [PubMed]

4. Hartz, T.K. The challenge of nutrition management of processing tomatoes in an era of rising yield expectations. Acta Hortic. 2017, 1159, 1-6. [CrossRef]

5. Ronga, D.; Francia, E.; Rizza, F.; Badeck, F.W.; Caradonia, F.; Montevecchi, G.; Pecchioni, N. Changes in yield components, morphological, physiological and fruit quality traits in processing tomato cultivated in Italy since the 1930's. Sci. Hortic. 2019, 257, 108726. [CrossRef]

6. Barrios-Masias, F.H.; Jackson, L.E. California processing tomatoes: Morphological, physiological and phenological traits associated with crop improvement during the last 80 years. Eur. J. Agron. 2014, 53, 45-55. [CrossRef]

7. Moura, L.E.D.; Golynski, A. Critical points of industrial tomato from field to processing. Horticulturae 2018, 36, 521-525. [CrossRef]

8. François-Xavier, B. Consumption Census 2015; Statistics Canada: Ottawa, BC, Canada, 2016.

9. Martínez-Hernández, G.B.; Boluda-Aguilar, M.; Taboada-Rodríguez, A.; Soto-Jover, S.; Marín-Iniesta, F.; López-Gómez, A. Processing, packaging, and storage of tomato products: Influence on the lycopene content. Food Eng. Rev. 2016, 8, 52-75. [CrossRef]

10. Svobodová, B.; Kubáň, V. Solanaceae: A family well-known and still surprising. In Phytochemicals in Vegetables: A Valuable Source of Bioactive Compounds; Petropoulos, S.A., Ferreira, I.C.F.R., Barros, L., Eds.; Bentham Science Publishers: Sharjah, United Arab Emirates, 2018; pp. 296-372. ISBN 9781681087399.

11. Raiola, A.; Tenore, G.C.; Barone, A.; Frusciante, L.; Rigano, M.M. Vitamin E content and composition in tomato fruits: Beneficial roles and bio-fortification. Int. J. Mol. Sci. 2015, 16, 29250-29264. [CrossRef]

12. Rowles, J.L.; Ranard, K.M.; Applegate, C.C.; Jeon, S.; An, R.; Erdman, J.W. Processed and raw tomato consumption and risk of prostate cancer: A systematic review and dose-response meta-analysis. Prostate Cancer Prostatic Dis. 2018, 21, 319-336. [CrossRef]

13. Shetty, A. Vegetables as Sources of Antioxidants. J. Food Nutr. Disord. 2013, 2, 1-5. [CrossRef]

14. George, B.; Kaur, C.; Khurdiya, D.S.; Kapoor, H.C. Antioxidants in tomato (Lycopersium esculentum) as a function of genotype. Food Chem. 2004, 84, 45-51. [CrossRef]

15. Kucuk, O.; Sarkar, F.H.; Sakr, W.; Djuric, Z.; Pollak, M.N.; Khachik, F.; Li, Y.W.; Banerjee, M.; Grignon, D.; Bertram, J.S.; et al. Phase II randomized clinical trial of lycopene supplementation before radical prostatectomy. Cancer Epidemiol. Biomark. Prev. 2001, 10, 861-868.

16. Ferreira, M.M.M.; Ferreira, G.B.; Fontes, P.C.R.; Dantas, J.P. Tomato plants production in relation to nitrogen doses and organic fertilization for two sowing times. Hortic. Bras. 2003, 21, 468-473. [CrossRef]

17. Castro Bustamante, S.; Hartz, T.K. Nitrogen management in organic processing tomato production: Nitrogen sufficiency prediction through early-season soil and plant monitoring. HortScience 2015, 50, 1055-1063. [CrossRef] 
18. Ronga, D.; Parisi, M.; Pentangelo, A.; Mori, M.; Mola, I. Di Effects of nitrogen management on biomass production and dry matter distribution of processing tomato cropped in southern Italy. Agronomy 2019, 9, 855. [CrossRef]

19. Hokam, E.M.; El-Hendawy, S.E.; Schmidhalter, U. Drip irrigation frequency: The effects and their interaction with nitrogen fertilization on maize growth and nitrogen use efficiency under arid conditions. J. Agron. Crop Sci. 2011, 197, 186-201. [CrossRef]

20. Jaynes, D.B.; Kaspar, T.C.; Colvin, T.S. Economically optimal nitrogen rates of corn: Management zones delineated from soil and terrain attributes. Agron. J. 2011, 10, 1026-1035. [CrossRef]

21. Farneselli, M.; Benincasa, P.; Tei, F. Validation of N nutritional status tools for processing tomato. Acta Hortic. 2010, 852, 227-232. [CrossRef]

22. Bloom, A.J. Interactions between Inorganic Nitrogen Nutrition and Root Development. Z. Pflanzenernähr. Bodenkd. 1997, 160, 253-259. [CrossRef]

23. Scholberg, J.; McNeal, B.L.; Boote, K.J.; Jones, J.W.; Locascio, S.J.; Olson, S.M. Nitrogen stress effects on growth and nitrogen accumulation by field-grown tomato. Agron. J. 2000, 92, 159-167. [CrossRef]

24. Seliga, J.P.; Shattuck, V.I. Crop rotation affects the yield and nitrogen fertilization response in processing tomatoes. Sci. Hortic. 1995, 64, 159-166. [CrossRef]

25. Bilalis, D.; Krokida, M.; Roussis, I.; Papastylianou, P.; Travlos, I.; Cheimona, N.; Dede, A. Effects of organic and inorganic fertilization on yield and quality of processing tomato (Lycopersicon esculentum Mill.). Folia Hortic. 2018, 30, 321-332. [CrossRef]

26. Farneselli, M.; Tosti, G.; Onofri, A.; Benincasa, P.; Guiducci, M.; Pannacci, E.; Tei, F. Effects of N sources and management strategies on crop growth, yield and potential N leaching in processing tomato. Eur. J. Agron. 2018, 98, 46-54. [CrossRef]

27. Farneselli, M.; Benincasa, P.; Tosti, G.; Simonne, E.; Guiducci, M.; Tei, F. High fertigation frequency improves nitrogen uptake and crop performance in processing tomato grown with high nitrogen and water supply. Agric. Water Manag. 2015, 154, 52-58. [CrossRef]

28. Tei, F.; Benincasa, P.; Farneselli, M.; Tosti, G.; Guiducci, M. Environmentally sustainable nitrogen nutrition management in processing tomato. Acta Hortic. 2015, 1081, 41-48. [CrossRef]

29. Fan, X.H.; Li, Y.C. Effects of slow-release fertilizers on tomato growth and nitrogen leaching. Commun. Soil Sci. Plant Anal. 2009, 40, 3452-3468. [CrossRef]

30. Carson, L.C.; Ozores-Hampton, M.; Morgan, K.T.; Sargent, S.A. Effects of controlled-release fertilizer nitrogen rate, placement, source, and release duration on tomato grown with seepage irrigation in Florida. HortScience 2014, 49, 798-806. [CrossRef]

31. Chen, D.A.; Suter, H.A.; Islam, A.A.; Edis, R.A.; Freney, J.R.A.; Walker, C.N.C. Prospects of improving efficiency of fertiliser nitrogen in Australian agriculture: A review of enhanced efficiency fertilisers. Aust. J. Soil Res. 2008, 46, 289-301. [CrossRef]

32. Li, Y.; Sun, Y.; Liao, S.; Zou, G.; Zhao, T.; Chen, Y.; Yang, J.; Zhang, L. Effects of two slow-release nitrogen fertilizers and irrigation on yield, quality, and water-fertilizer productivity of greenhouse tomato. Agric. Water Manag. 2017, 186, 139-146. [CrossRef]

33. Guertal, E.A. Slow-release nitrogen fertilizers in vegetable production: A review. Horttechnology 2009, 19, 16-19. [CrossRef]

34. Safiul Azam, F.M.; Al Labib, B.; Jabin, D.; Rahman Sayeed, M.S.; Islam, S.; Akter, S.; Khan Eusufzai, T.; Siddique, M.R.; Ismail Khan, H.M.; Jahan, R.; et al. Study on synergistic effect of Zeolite and supplementary fertilizer in soil on flowering of Solanum melongena L. (Solanaceae) and growth of Citrus aurantiifolia (Christm.) Swingle (Rutaceae). Am. J. Sustain. Agric. 2013, 7, 108-113.

35. Li, Z.; Zhang, Y.; Li, Y. Zeolite as slow release fertilizer on spinach yields and quality in a greenhouse test. J. Plant Nutr. 2013, 36, 1496-1505. [CrossRef]

36. Leggo, P.J.; Ledésert, B.; Christie, G. The role of clinoptilolite in organo-zeolitic-soil systems used for phytoremediation. Sci. Total Environ. 2006, 363, 1-10. [CrossRef] [PubMed]

37. Litaor, M.I.; Katz, L.; Shenker, M. The influence of compost and zeolite co-addition on the nutrients status and plant growth in intensively cultivated Mediterranean soils. Soil Use Manag. 2017, 33, 72-80. [CrossRef]

38. Rosalina, F.; Gafur, M.A.A.; Irnawati, I.; Soekamto, M.H.; Sangadji, Z.; Kahar, S.M. Utilization of compost and zeolite as ameliorant on quartz sand planting media for caisim (Brassica juncea) plant growth. J. Phys. 2019, 1155, 012055. [CrossRef] 
39. Jahanbakhshi, A.; Kheiralipour, K. Influence of vermicompost and sheep manure on mechanical properties of tomato fruit. Food Sci. Nutr. 2019, 7, 1172-1178. [CrossRef] [PubMed]

40. Kaniszewski, S.; Kosson, R.; Grzegorzewska, M.; Kowalski, A.; Badełek, E.; Rzybowska, J.; Tuccio, L.; Agati, G. Yield and quality traits of field grown tomato as affected by cultivar and nitrogen application rate. J. Agric. Sci. Technol. 2019, 21, 683-697.

41. Petropoulos, S.A.; Fernandes, Â.; Polyzos, N.; Antoniadis, V.; Barros, L.; Ferreira, I. The Impact of fertilization regime on the crop performance and chemical composition of potato (Solanum tuberosum L.) cultivated in central Greece. Agronomy 2020, 10, 474. [CrossRef]

42. Karkanis, A.C.; Petropoulos, S.A. Physiological and growth responses of several genotypes of common purslane (Portulaca oleracea L.) under Mediterranean semi-arid conditions. Not. Bot. Horti Agrobot. Cluj Napoca 2017, 45, 569-575. [CrossRef]

43. Petropoulos, S.A.; Fernandes, Â.; Barros, L.; Ferreira, I.C.F.R.; Ntatsi, G. Morphological, nutritional and chemical description of "vatikiotiko", an onion local landrace from Greece. Food Chem. 2015, 182, 156-163. [CrossRef]

44. Petropoulos, S.A.; Olympios, C.; Ropokis, A.; Vlachou, G.; Ntatsi, G. Fruit volatiles, quality, and yield of watermelon as affected by grafting. J. Agric. Sci. Technol. 2014, 16, 873-885.

45. AOAC. Official Methods of Analysis of Association of Official Analytical Chemists International. In Official Methods of Analysis of AOAC International; Horwitz, W., Latimer, G., Eds.; AOAC: Gaithersburg, MD, USA, 2016; ISBN 0935584773.

46. Silva, A.R.; Fernandes, Â.; García, P.A.; Barros, L.; Ferreira, I.C.F.R. Cytinus hypocistis (L.) L. subsp. macranthus Wettst.: Nutritional characterization. Molecules 2019, 24, 1-10.

47. Pereira, C.; Barros, L.; Carvalho, A.M.; Ferreira, I.C.F.R. Use of UFLC-PDA for the analysis of organic acids in thirty-five species of food and medicinal plants. Food Anal. Methods 2013, 6, 1337-1344. [CrossRef]

48. Petropoulos, S.A.; Fernandes, Â.; Katsoulas, N.; Barros, L.; Ferreira, I.C.F.R. The effect of covering material on the yield, quality and chemical composition of greenhouse-grown tomato fruit. J. Sci. Food Agric. 2019, 99, 3057-3068. [CrossRef] [PubMed]

49. Petropoulos, S.; Fernandes, Â.; Karkanis, A.; Antoniadis, V.; Barros, L.; Ferreira, I.C.F.R. Nutrient solution composition and growing season affect yield and chemical composition of Cichorium spinosum plants. Sci. Hortic. 2018, 231, 97-107. [CrossRef]

50. Du, Y.D.; Cao, H.; Liu, S.; Gu, X.; Cao, Y. Response of yield, quality, water and nitrogen use efficiency of tomato to different levels of water and nitrogen under drip irrigation in Northwestern China. J. Integr. Agric. 2017, 16, 1153-1161. [CrossRef]

51. Biswas, M.; Sarkar, D.R.; Asif, M.I.; Sikder, R.K.; Mehraj, H.; Jamal Uddin, A.F.M. Nitrogen levels on morphological and yield response of BARI tomato-9. J. Sci. Technol. Environ. Inf. 2015, 1, 68-74. [CrossRef]

52. Baloch, Q.B.; Hussain, A.; Wahocho, N.A.; Baloch, N.A.; Wahocho, S.A.; Kaleri, A.A.; Kaleri, R.R.; Gola, A.Q. Response of various nitrogen levels on the growth and yield performance of tomato (Lycopersicon esculentum Mill.). J. Basic Appl. Sci. 2017, 13, 583-588.

53. Elia, A.; Conversa, G. Agronomic and physiological responses of a tomato crop to nitrogen input. Eur. J. Agron. 2012, 40, 64-74. [CrossRef]

54. Benincasa, P.; Guiducci, M.; Tei, F. The nitrogen use efficiency: Meaning and sources of variation-case studies on three vegetable crops in central Italy. Horttechnology 2011, 21, 266-273. [CrossRef]

55. Marouelli, W.A.; Souza, R.B.; Braga, M.B.; Silva, W.L. Evaluation of sources, doses and application schedules of nitrogen on drip-irrigated tomato. Hortic. Bras. 2014, 32, 327-335. [CrossRef]

56. Zhang, T.Q.; Tan, C.S.; Liu, K.; Drury, C.F.; Papadopoulos, A.P.; Warner, J. Yield and economic assessments of fertilizer nitrogen and phosphorus for processing tomato with drip fertigation. Agron. J. 2010, 102, 774-780. [CrossRef]

57. Ronga, D.; Lovelli, S.; Zaccardelli, M.; Perrone, D.; Ulrici, A.; Francia, E.; Milc, J.; Pecchioni, N. Physiological responses of processing tomato in organic and conventional Mediterranean cropping systems. Sci. Hortic. 2015, 190, 161-172. [CrossRef]

58. Mukta, S.; Rahman, M.; Mortuza, M. Yield and nutrient content of tomato as influenced by the application of vermicompost and chemical fertilizers. J. Environ. Sci. Nat. Resour. 2016, 8, 115-122. [CrossRef]

59. Parisi, M.; Giordano, L.; Pentangelo, A.; D'Onofrio, B.; Villari, G. Effects of different levels of nitrogen fertilization on yield and fruit quality in processing tomato. Acta Hortic. 2006, 700, 129-132. [CrossRef] 
60. Zuba, S.; Nogueira, W.; Fernandes, L.; Sampaio, R.; Costa, C. Yield and nutrition of tomato using different nutrient sources. Hortic. Bras. 2011, 29, 50-56. [CrossRef]

61. Abu-Alrub, I.; Saleh, S.; Awaga, A.A. Effect of different rates of nitrogen and phosphorus fertilizers on yield and quality of greenhouse tomato Under the UAE condition. EC Agric. 2019, 5, 139-146.

62. Kalbani, F.O.S.A.; Salem, M.A.; Cheruth, A.J.; Kurup, S.S.; Senthilkumar, A. Effect of some organic fertilizers on growth, yield and quality of tomato (Solanum lycopersicum). Int. Lett. Nat. Sci. 2016, 53, 1-9. [CrossRef]

63. Chehade, L.A.; Antichi, D.; Martelloni, L.; Frasconi, C.; Sbrana, M.; Mazzoncini, M.; Peruzzi, A. Evaluation of the agronomic performance of organic processing tomato as affected by different cover crop residues management. Agronomy 2019, 9, 504. [CrossRef]

64. Colla, G.; Mitchell, J.P.; Poudel, D.D.; Saccardo, F. Impacts of farming systems and soil characteristics on processing tomato fruit quality. Acta Hortic. 2001, 542, 333-341. [CrossRef]

65. Polat, E.; Demir, H.; Erler, F. Yield and quality criteria in organically and conventionally grown tomatoes in Turkey. Sci. Agric. 2010, 67, 424-429. [CrossRef]

66. Ewulo, B.S.; Ojeniyi, S.O.; Akanni, D.A. Effect of poultry manure on selected soil physical and chemical properties, growth, yield and nutrient status of tomato. Afr. J. Agric. Res. 2008, 3, 9-14.

67. Petropoulos, S.A.; Fernandes, Â.; Dias, M.I.; Pereira, C.; Calhelha, R.; Gioia, F.D.; Tzortzakis, N.; Ivanov, M.; Sokovic, M.; Barros, L.; et al. Wild and cultivated Centaurea raphanina subsp. mixta: A valuable source of bioactive compounds. Antioxidants 2020, 9, 314. [CrossRef]

68. Zushi, K.; Matsuzoe, N. Metabolic profile of organoleptic and health-promoting qualities in two tomato cultivars subjected to salt stress and their interactions using correlation network analysis. Sci. Hortic. 2015, 184, 8-17. [CrossRef]

69. Navarro-González, I.; García-Valverde, V.; García-Alonso, J.; Periago, M.J. Chemical profile, functional and antioxidant properties of tomato peel fiber. Food Res. Int. 2011, 44, 1528-1535. [CrossRef]

70. Samaila, A.; Amans, E.B.; Abubakar, I.U.; Ahmad Babaji, B. Nutritional quality of tomato (Lycopersicon esculentum Mill) as influenced by mulching, nitrogen and irrigation interval. J. Agric. Sci. 2011, 3, $266-270$. [CrossRef]

71. Abushita, A.A.; Daood, H.G.; Biacs, P.A. Change in carotenoids and antioxidant vitamins in tomato as a function of varietal and technological factors. J. Agric. Food Chem. 2000, 48, 2075-2081. [CrossRef]

72. Saini, R.K.; Zamany, A.J.; Keum, Y.S. Ripening improves the content of carotenoid, $\alpha$-tocopherol, and polyunsaturated fatty acids in tomato (Solanum lycopersicum L.) fruits. 3 Biotech 2017, 7, 43. [CrossRef]

73. Seybold, C.; Fröhlich, K.; Bitsch, R.; Otto, K.; Böhm, V. Changes in contents of carotenoids and vitamin E during tomato processing. J. Agric. Food Chem. 2004, 52, 7005-7010. [CrossRef]

74. Kacjan Maršić, N.; Šircelj, H.; Kastelec, D. Lipophilic antioxidants and some carpometric characteristics of fruits of ten processing tomato varieties, grown in different climatic conditions. J. Agric. Food Chem. 2010, 58, 390-397. [CrossRef]

75. Helyes, L.; Lugasi, A.; Daood, H.G.; Pék, Z. The simultaneous effect of water supply and genotype on yield quantity, antioxidants content and composition of processing tomatoes. Not. Bot. Horti Agrobot. Cluj Napoca 2014, 42, 143-149. [CrossRef]

76. Pék, Z.; Szuvandzsiev, P.; Daood, H.; Neményi, A.; Helyes, L. Effect of irrigation on yield parameters and antioxidant profiles of processing cherry tomato. Open Life Sci. 2014, 9, 383-395. [CrossRef]

77. Kalogeropoulos, N.; Chiou, A.; Pyriochou, V.; Peristeraki, A.; Karathanos, V.T. Bioactive phytochemicals in industrial tomatoes and their processing byproducts. LWT Food Sci. Technol. 2012, 49, 213-216. [CrossRef]

78. García Herrera, P.; Sánchez-Mata, M.C.; Cámara, M. Nutritional characterization of tomato fiber as a useful ingredient for food industry. Innov. Food Sci. Emerg. Technol. 2010, 11,707-711. [CrossRef]

79. Anthon, G.E.; Lestrange, M.; Barrett, D.M. Changes in $\mathrm{pH}$, acids, sugars and other quality parameters during extended vine holding of ripe processing tomatoes. J. Sci. Food Agric. 2011, 91, 1175-1181. [CrossRef]

80. Lahoz, I.; Leiva-Brondo, M.; Martí, R.; Macua, J.I.; Campillo, C.; Roselló, S.; Cebolla-Cornejo, J. Influence of high lycopene varieties and organic farming on the production and quality of processing tomato. Sci. Hortic. 2016, 204, 128-137. [CrossRef]

81. Valcárcel, M.; Lahoz, I.; Campillo, C.; Martí, R.; Leiva-Brondo, M.; Roselló, S.; Cebolla-Cornejo, J. Controlled deficit irrigation as a water-saving strategy for processing tomato. Sci. Hortic. 2020, 261, 108972. [CrossRef] 
82. Bénard, C.; Gautier, H.; Bourgaud, F.; Grasselly, D.; Navez, B.; Caris-Veyrat, C.; Weiss, M.; Génard, M. Effects of low nitrogen supply on tomato (Solanum lycopersicum) fruit yield and quality with special emphasis on sugars, acids, ascorbate, carotenoids, and phenolic compounds. J. Agric. Food Chem. 2009, 57, 4112-4123. [CrossRef]

83. Wei, Z.; Du, T.; Li, X.; Fang, L.; Liu, F. Interactive effects of elevated CO2 and N fertilization on yield and quality of tomato grown under reduced irrigation regimes. Front. Plant Sci. 2018, 9, 1-10. [CrossRef]

84. Dabire, C.; Sereme, A.; Parkouda, C.; Somda, M.K.; Traore, A.S. Influence of organic and mineral fertilizers on chemical and biochemical compounds content in tomato (Solanum lycopersicum) var. Mongal F1. J. Exp. Biol. Agric. Sci. 2016, 4, 631-636.

85. Pieper, J.R.; Barrett, D.M. Effects of organic and conventional production systems on quality and nutritional parameters of processing tomatoes. J. Sci. Food Agric. 2009, 89, 177-194. [CrossRef]

86. Zhang, Y.P.S.Y.; Lin, X.Y.; Zhang, Y.P.S.Y.; Zheng, S.J.; Du, S.T. Effects of nitrogen levels and nitrate/ammonium ratios on oxalate concentrations of different forms in edible parts of spinach. J. Plant Nutr. 2005, 28, 2011-2025. [CrossRef]

87. Petropoulos, S.A.; Fernandes, Â.; Calhelha, R.C.; Di Gioia, F.; Kolovou, P.; Barros, L.; Ferreira, I.C.F.R. Chemical composition and bioactive properties of Cichorium spinosum L. in relation to nitrate/ammonium nitrogen ratio. J. Sci. Food Agric. 2019, 99, 6741-6750. [CrossRef] [PubMed]

88. Palaniswamy, U.R.; McAvoy, R.J.; Bible, B. Oxalic acid concentrations in purslane (Portulaca oleraceae L.) is altered by the stage of harvest and the nitrate to ammonium ratios in hydroponics. Sci. Hortic. 2004, 629, 299-305.

89. Ramesh, K.; Reddy, D.D.; Biswas, A.K.; Rao, A.S. Zeolites and their potential uses in agriculture. Adv. Agron. 2011, 113, 219-241.

90. Heeb, A.; Lundegårdh, B.; Savage, G.; Ericsson, T. Impact of organic and inorganic fertilizers on yield, taste, and nutritional quality of tomatoes. J. Plant Nutr. Soil Sci. 2006, 169, 535-541. [CrossRef]

91. Vinha, A.F.; Alves, R.C.; Barreira, S.V.P.; Castro, A.; Costa, A.S.G.; Oliveira, M.B.P.P. Effect of peel and seed removal on the nutritional value and antioxidant activity of tomato (Lycopersicon esculentum L.) fruits. LWT Food Sci. Technol. 2014, 55, 197-202. [CrossRef]

92. Toor, R.K.; Savage, G.P. Antioxidant activity in different fractions of tomatoes. Food Res. Int. 2005, 38, 487-494. [CrossRef]

93. Verma, S.; Sharma, A.; Kumar, R.; Kaur, C.; Arora, A.; Shah, R.; Nain, L. Improvement of antioxidant and defense properties of tomato (var. Pusa Rohini) by application of bioaugmented compost. Saudi J. Biol. Sci. 2015, 22, 256-264. [CrossRef]

94. Zhang, E.; Duan, Y.; Tan, F.; Zhang, S. Effects of long-term nitrogen and organic fertilization on antioxidants content of tomato fruits. J. Hortic. 2016, 3, 8-12. [CrossRef]

95. AL-Kahtani, S.; Ahmed, M.; Al-Selwey, W.; Abdel-Razzak, H. Evaluation of composted agricultural crop wastes application on growth, mineral content, yield, and fruit quality of tomato. J. Exp. Biol. Agric. Sci. 2018, 6, 159-167.

96. Arthanari, M.; Dhanapalan, S. Quantification of $\beta$-carotene, lycopene, and chlorophyll content in tomato fruits of enrichment of chicken feathers composting. Int. J. Recycl. Org. Waste Agric. 2019, 8, 473-477. [CrossRef]

97. Shi, J.; Le Maguer, M. Lycopene in tomatoes: Chemical and physical properties affected by food processing. Crit. Rev. Biotechnol. 2000, 20, 293-334. [CrossRef] [PubMed]

98. García-Valverde, V.; Navarro-González, I.; García-Alonso, J.; Periago, M.J. Antioxidant bioactive compounds in selected industrial processing and fresh consumption tomato cultivars. Food Bioprocess. Technol. 2013, 6, 391-402. [CrossRef]

99. Cámara, M.; de Cortes Sánchez-Mata, M.; Fernández-Ruiz, V.; Cámara, R.M.; Manzoor, S.; Caceres, J.O. Lycopene: A Review of Chemical and Biological Activity Related to Beneficial Health Effects. In Studies in Natural Products Chemistry; Atta-ur-Rahman, B.T.-S., Ed.; Elsevier: Amsterdam, The Netherlands, 2013; Volume 40, pp. 383-426. ISBN 1572-5995.

100. Petropoulos, S.; Karkanis, A.; Fernandes, Â.; Barros, L.; Ferreira, I.C.F.R.; Ntatsi, G.; Petrotos, K.; Lykas, C.; Khah, E. Chemical composition and yield of six genotypes of common purslane (Portulaca oleracea L.): An alternative source of omega-3 fatty acids. Plant Foods Hum. Nutr. 2015, 70, 420-426. [CrossRef] 
101. Guil, J.L.; Torija, M.E.; Giménez, J.J.; Rodriguez, I. Identification of fatty acids in edible wild plants by gas chromatography. J. Chromatogr. A 1996, 719, 229-235. [CrossRef]

102. Martínez-Valverde, I.; Periago, M.J.; Provan, G.; Chesson, A. Phenolic compounds, lycopene and antioxidant activity in commercial varieties of tomato (Lycopersicum esculentum). J. Sci. Food Agric. 2002, 82, 323-330. [CrossRef]

103. Szabo, K.; Diaconeasa, Z.; Cătoi, A.F.; Vodnar, D.C. Screening of ten tomato varieties processing waste for bioactive components and their related antioxidant and antimicrobial activities. Antioxidants 2019, 8, 292. [CrossRef]

104. Raiola, A.; Del Giudice, R.; Monti, D.M.; Tenore, G.C.; Barone, A.; Rigano, M.M. Bioactive compound content and cytotoxic effect on human cancer cells of fresh and processed yellow tomatoes. Molecules 2016, 21, 33. [CrossRef]

105. Fuentes, E.; Carle, R.; Astudillo, L.; Guzmán, L.; Gutiérrez, M.; Carrasco, G.; Palomo, I. Antioxidant and antiplatelet activities in extracts from green and fully ripe tomato fruits (Solanum lycopersicum) and pomace from industrial tomato processing. Evid. Based Complement. Altern. Med. 2013, 2013,1-9. [CrossRef]

106. Floegel, A.; Kim, D.O.; Chung, S.J.; Koo, S.I.; Chun, O.K. Comparison of ABTS/DPPH assays to measure antioxidant capacity in popular antioxidant-rich US foods. J. Food Compos. Anal. 2011, 24, 1043-1048. [CrossRef]

107. Kollia, E.; Markaki, P.; Zoumpoulakis, P.; Proestos, C. Antioxidant activity of Cynara scolymus L. and Cynara cardunculus L. extracts obtained by different extraction techniques. Nat. Prod. Res. 2016, 31, 1163-1167. [CrossRef] [PubMed]

108. Choi, S.H.; Kim, D.S.; Kozukue, N.; Kim, H.J.; Nishitani, Y.; Mizuno, M.; Levin, C.E.; Friedman, M. Protein, free amino acid, phenolic, $\beta$-carotene, and lycopene content, and antioxidative and cancer cell inhibitory effects of 12 greenhouse-grown commercial cherry tomato varieties. J. Food Compos. Anal. 2014, 34, 115-127. [CrossRef]

109. Ilić, Z.S.; Kapoulas, N.; Šunić, L. Tomato Fruit Quality from Organic and Conventional Production; Books on Demand: Norderstedt, Germany, 2014.

110. Toor, R.K.; Savage, G.P.; Heeb, A. Influence of different types of fertilisers on the major antioxidant components of tomatoes. J. Food Compos. Anal. 2006, 19, 20-27. [CrossRef]

111. Sereme, A.; Dabire, C.; Koala, M.; Somda, M.K.; Traore, A.S. Influence of organic and mineral fertilizers on the antioxidants and total phenolic compounds level in tomato (Solanum lycopersicum) var. mongal F1. J. Exp. Biol. Agric. Sci. 2016, 4, 414-420. 